OPEN ACCESS

Edited by:

Jia-bo Wang,

Fifth Medical Center of the PLA

General Hospital, China

Reviewed by:

Priyia Pusparajah

Monash University Malaysia, Malaysia

Ming Yen Tsai,

Kaohsiung Chang Gung Memorial

Hospital, Taiwan

*Correspondence:

Run-Chun Xu

309786953@qq.com

Ding-Kun Zhang

465790643@qq.com

Specialty section: This article was submitted to

Ethnopharmacology,

a section of the journal

Frontiers in Pharmacology

Received: 14 July 2020 Accepted: 28 January 2021

Published: 22 March 2021

Citation:

Ma LL, Liu HM, Luo CH, He YN, Wang $F$, Huang $H Z$, Han L, Yang M, Xu RC and Zhang DK (2021) Fever and Antipyretic Supported by Traditional

Chinese Medicine: A Multi-

Pathway Regulation.

Front. Pharmacol. 12:583279.

doi: 10.3389/fphar.2021.583279

\section{Fever and Antipyretic Supported by Traditional Chinese Medicine: A Multi-Pathway Regulation}

\author{
Le-Le Ma ${ }^{1}$, Hui-Min Liu ${ }^{1}$, Chuan-Hong Luo ${ }^{1}$, Ya-Nan He ${ }^{1}$, Fang Wang ${ }^{2}$, Hao-Zhou Huang ${ }^{1}$, \\ Li Han ${ }^{1}$, Ming Yang ${ }^{2}$, Run-Chun Xu ${ }^{1 *}$ and Ding-Kun Zhang ${ }^{1 *}$ \\ ${ }^{1}$ State Key Laboratory of Southwestern Chinese Medicine Resources, Pharmacy School, Chengdu University of Traditional \\ Chinese Medicine, Chengdu, PR China, ${ }^{2}$ State key Laboratory of Innovation Medicine and High Efficiency and Energy Saving \\ Pharmaceutical Equipment, Jiangxi University of Traditional Chinese Medicine, Nanchang, PR China
}

The coronavirus disease, 2019 (COVID-19), has spread rapidly around the world and become a major public health problem facing the world. Traditional Chinese medicine (TCM) has been fully committed to treat COVID-19 in China. It improved the clinical symptoms of patients and reduced the mortality rate. In light of the fever was identified as one of leading clinical features of COVID-19, this paper will first analyze the material basis of fever, including pyrogenic cytokines and a variety of the mediators of fever. Then the humoral and neural pathways of fever signal transmission will be described. The scattered evidences about fever recorded in recent years are connected in series. On this basis, the understanding of fever is further deepened from the aspects of pathology and physiology. Finally, combining with the chemical composition and pharmacological action of available TCM, we analyzed the mechanisms of TCMs to play the antipyretic effect through multiple ways. So as to further provide the basis for the research of antipyretic compound preparations of TCMs and explore the potential medicines for the prevention and treatment of COVID-19.

Keywords: COVID-19, fever, antipyretic, traditional chinese medicine, mechanism, bioactive components

\section{INTRODUCTION}

COVID-19 has become a major threat to worldwide public health, having rapidly spread to more than 180 countries and infecting over 1.6 billion people. Fever, cough, diarrhea, and fatigue are the most common initial symptoms of COVID-19 (Luo et al., 2020a). However, fever was identified as leading clinical feature. A study of the clinical progression of COVID-19 patients in Shanghai, China, included 249 confirmed cases of COVID-19 from Jan 20 to Feb 6, 2020. The research found that as high as $94.3 \%$ of the patients, including those who were afebrile on admission had fever. The estimated median duration of fever in all the patients with fever was 10 days after onset of symptoms. Patients who were transferred to ICU had significantly longer duration of fever as compared to those who were stable, up to 31 days (Chen et al., 2020). Clinical data from another study showed that only $43.8 \%$ of patients presented with a fever, but $88.7 \%$ developed a fever after hospitalization, indicating the afebrile patients may be at the early stage of the disease (Guan et al., 2020). Therefore, preventive treatment should be carried out for a large number of suspected cases and their close contacts in order to reduce the possibility of infection and block the spread of COVID-19. In addition, timely treatment of confirmed patients can prevent further deterioration of the disease, reduce the chance of patients with mild symptoms becoming serious. In light of fever was the most common initial 
TABLE 1 | Descriptive table of the Chinese herbal medicines mentioned in this paper.

\begin{tabular}{|c|c|c|c|c|}
\hline Scientific name & English name & Common name & $\begin{array}{l}\text { Local } \\
\text { chinesename }\end{array}$ & Parts used \\
\hline Bupleurum chinense DC. and Bupleurum scorzonerifolium Willd & Bupleuri radix & Chinese thorowax root & Chai-hu & Root \\
\hline Scutellaria baicalensis Georgi & Scutellariae radix & Baical skullcap root & Huang-qin & Root \\
\hline $\begin{array}{l}\text { Conioselinum anthriscoides 'Chuanxiong' } \\
\text { (syn. Ligusticum chuanxiong Hort) }\end{array}$ & Chuanxiong rhizome & Rhizoma ligustici wallichii & Chuan-xiong & Root \\
\hline Cinnamomum cassia (L.) J.Presl & Cinnamomi ramulus & Cassia twig & Gui-zhi & Branch \\
\hline Forsythia suspensa (Thunb.) Vahl & Forsythiae Fructus & Forsythia & Liao-qiao & Fruit \\
\hline Lonicera japonica Thunb & Lonicera japonica Flos & Honeysuckle flower & Jin-yin-hua & Flower \\
\hline \multirow{2}{*}{$\begin{array}{l}\text { Ephedra sinica Stapf, Ephedra intermedia Schrenk et C. A. Mey and Ephedra } \\
\text { equisetina Bunge. }\end{array}$} & Ephedrae Herba & Ephedra erial parts & Ma-huang & Erial parts \\
\hline & Gypsum Ustum & Gypsum & Shi-gao & \\
\hline $\begin{array}{l}\text { Pueraria montana var. Iobata (Willd.) Maesen \& S.M.Almeida ex } \\
\text { Sanjappa \& Predeep (syn. Pueraria lobata (Willd.) Ohw) }\end{array}$ & Puerariae Lobatae radix & Kudzu root & Ge-gen & Root \\
\hline Bubalus bubalis Linnaeus & Bubali Cornu & Buffalo horn & Shui-niu-jiao & Horn \\
\hline Houttuynia cordata Thunb & Houttuyniae Herba & Cordate houttuynia & Yu-xing-cao & Herb \\
\hline Gardenia jasminoides J.Ellis & Gardeniae Fructus & Gardenia & Zhi-zi & Fruit \\
\hline Andrographis paniculata (Burm.f.) Nees & Andrographis Herba & Herba andrographitis & Chuan-xin-lian & Herb \\
\hline
\end{tabular}

symptom in patients with COVID-19, it is of great significance to understand the mechanisms of fever and take antipyretic measures for diagnosis, treatment and prognosis of COVID-19 patients.

Currently, the treatment of fever includes physical cooling and antipyretic medications such as NSAIDs and Paracetamol. Research has shown that patients with moderate fever should avoid active cooling because it increases the metabolic rate, activates the autonomic nervous system, and provokes thermal discomfort (Lenhardt et al., 1999). In addition, on March 16th' 2020, the French Minister of Health has announced that NSAIDs may worsen clinical conditions of patients with COVID-19 based on the evaluation of four patients affected by the disease (Capuano et al., 2020). Some authors have suggested that NSAIDs, particularly Ibuprofen, may induce increased sensitivity to more severe clinical features in COVID-19 infection (Laura et al., 2020). They argued that coronaviruses bind to angiotensin-converting enzyme-2 (ACE-2), and ibuprofen administration can increase the bioavailability of ACE-2, thus potentiating and enhancing the infectious processes of coronaviruses (Fang et al., 2020). Since nowadays no scientific evidence establishes a correlation between NSAIDS and the worsening of COVID-19, patients should be advised against NSAIDs when COVID-19 like symptoms begins (Fang et al., 2020). Although it has been suggested that patients could take paracetamol to treat the symptoms of COVID-19, overdose or long-term use of Paracetamol can also produce the largely irreversible hepatotoxicity and incipient gastric toxicity (Whitehouse and Butters, 2014). Therefore, it is essential to explore a safe, effective, and low toxicity treatment method. TCM has attracted global attention due to its low toxicity and high efficacy. According to clinical observations, the common symptoms of fever subsided by more than $90 \%$ of the 3,698 patients with COVID-19 within 1.74 days on average when the indicated TCM formulation was commenced (Li et al., 2020). TCM has been used to treat fever for more than 2000 years. Many years of clinical observations and several published studies suggest single Chinese medicine and compound preparations of TCM have specific antipyretic effects; these include Bupleuri Radix (Idrisusman et al., 2010), Scutellariae Radix (Tsai et al., 2006), Lonicera Japonica Flo (Xie et al., 2009), Shuang-HuangLian injection (Huang et al., 2019), Qingkailing injection (Zhang et al., 2017) and so on.

In this paper, through the systematic analysis of the mechanisms of fever, combined with the chemical composition and pharmacological action of TCM (Table 1), we analyzed the material basis, mechanisms, and characteristics of the antipyretic action of single TCM and its compound preparations to deepen the theory of TCM from the micro-level, and to develop safer and effective antipyretic preparations of TCM, as well as improve the treatment level and promote the rehabilitation of patients with COVID-19.

\section{THE DEFINITION OF FEVER}

After three revisions, the Commission for Thermal Physiology of the International Union of Physiological Sciences defined fever as the elevation of the set-point of body temperature due to a change in the thermo controller characteristics. It is usually part of the defense response of organism (host) to the invasion of pathogenic or foreign living (microorganism) or inanimate substances. At this level, the core temperature will be maintained for a period of time (Sciences, 2003). In a normal healthy individual, the thermal regulatory network of the body maintains a temperature of $36.2-37.5^{\circ} \mathrm{C}$ (Prajitha et al., 2019). Many medical and clinical studies regard rectal temperature of $\geq 38^{\circ} \mathrm{C}$ or axillary temperature $\geq 37.5^{\circ} \mathrm{C}$ as indicative of fever (Shu et al., 2016). It is worth noting that not all temperature increases can be defined as fever. Clinically, there are 2 cases of typical temperature increase: fever and hyperthermia. Contrary to fever, in hyperthermia, the set-point is unchanged; it occurs in response to specific environmental, pharmacologic, or endocrine stimuli. The elevated body temperature that occurs in hyperthermia 
syndrome can exceed $41.0^{\circ} \mathrm{C}$ (Niven et al., 2013). Hyperthermia does not respond to typical antipyretics since there are no pyrogenic molecules (Dewitt et al., 2017); this distinguishes fever from hyperthermia.

\section{THE MATERIAL BASIS OF FEVER}

\section{Pyrogenic Cytokines}

In 1948, Beeson obtained a substance from the granulocytes of the sterile peritoneal exudate of rabbits, which would raise the body temperature of normal rabbits after injection (Beeson, 1948). Subsequently, similar substances were discovered in other febrile animal models, resulting in the release of an elaborated endogenous pyrogen in consequence of the stimulation by exogenous pyrogens (Dinarello, 1999). Howeve, some endogenous substances, such as autoantibody complexes, inflammatory bile acids, may act as pyrogen without exogenous pyrogens induction (Sajadi, 2015). With the acceptance of the term cytokine, the term endogenous pyrogen is no longer appropriate. In order to differentiate cytokines that are intrinsically pyrogenic from those that are not, it is more appropriate to define them as pyrogenic cytokines (Dinarello, 2004).

The pyrogenic cytokine is a part of the autoimmune system. Invasion of a host by exogenous pyrogens triggers a series of immune responses through pathogen-associated molecular patterns (PAMPs), including LPS, lipoarabinomannans, lipoteichoic acid, and viral RNA (Evans et al., 2015; Kumar et al., 2011). PAMPs act through pattern recognition receptors, such as toll-like receptors (TLRs), on immune cells to induce the release of pyrogenic cytokines (Prajitha et al., 2018). The currently recognized major pyrogenic cytokines are interleukin-1 (IL-1), interleukin-6 (IL-6), tumor necrosis factor $\alpha$ (TNF- $\alpha$ ) (Conti et al., 2004). Systemic injection of LPS in animal models can increase the release of these cytokines into the general circulation (Harré et al., 2002). LPS stimulate TLRs, specifically TLR4, inducing the release of pyrogenic cytokine that induce fever.

\section{IL-1}

IL-1 is a prototypical inflammatory cytokine for neuroimmune communication. Discovery of the actions of IL-1 in the macrophages, fibroblasts B cells, endothelium, and large granular lymphocytes, showed that IL-1 represents two different molecular forms (IL-1 $\alpha$ and IL-1 $\beta$ ) and an endogenous IL-1 receptor antagonist (IL-1RA) (Equils et al., 2020). The study demonstrated that IL- 1 is essential in the induction of fever as a central injection or intraperitoneal injection of IL-1RA caused significant inhibition of LPSinduced fever (Miller et al., 1997; Smith and Kluger, 1992). In addition, it has been shown that many species can cause fever response to peripheral injection of IL- $1 \alpha$ and IL-1 $\beta$ (Dinarello, 1996; Kluger, 1991). The present explanation for this is that IL-1 induces intermediates, prostaglandin E2 (PGE2), and cyclooxygenase-2 (COX-2), which are considered necessary downstream events that mediate peripheral IL-1-induced fever
(Ching et al., 2007; Li et al., 2001). IL-1 induced COX-2 and PGE2 depends on the expression of the mitogen-activated protein kinase kinase kinase 7 (MAP3K7) also known as TAK1. It is most likely to induce COX-2 by activating MAPKP38 and c-Jun, which are necessary for fever induction (Ridder et al., 2011). IL-1 activates the inhibitor of nuclear factor B (IKB) kinase 2 (IKK2), which binds to polyubiquitin chains on several upstream molecules, includingTAK1 and TAB3. Activated IKK phosphorylates nuclear factor- $\kappa \mathrm{B}(\mathrm{NF}-\kappa \mathrm{B})$ inhibitor $\alpha$ (I $\mathrm{B} \mathrm{B} \alpha)$ and then activates NF- $\kappa B$ (Weber et al., 2010). The rapid activation of the NF- $\kappa \mathrm{B}$ pathway induced by IL-1 has been proven to be the cause of COX-2 production in cerebrovascular endothelial cells (Nadjar et al., 2005). Therefore, IL-1 can also induce the production of COX-2 and PGE2 by activating the NF- $\kappa \mathrm{B}$ pathway.

\section{IL-6}

IL-6 is produced under a variety of stimuli including tissue damage, viruses, or other proinflammatory cytokines. It is secreted by innate immune cells, as well as endothelial cells, fibroblasts, astrocytes, and epithelial cells (Rincon, 2012). The IL6 during inflammation and infection is induced via stimulation of cells by IL-1 or TNF- $\alpha$ or through stimulation of TLRSs after binding of PAMPs (Kang et al., 2019). Receptors for IL-6 exist in two forms: a soluble receptor (sIL-6R) and a membrane-bound receptor (IL-6R) (Uciechowski and Dempke, 2020). Studies have shown that IL-6 knockout mice, as well as in animals treated with IL-6 antiserum, produced no febrile response to the peripheral immune response, suggesting that the existence of IL- 6 is very important for fever (Nilsberth et al., 2009). IL-6 produced by nonhematopoietic cells is the key component of LPS induced fever; IL- 6 produced by hematopoietic cells plays a secondary role in the production of systemic IL-6. However, the phenotype of these cells is unknown and may involve multiple cell types, requiring further study (Hamzic et al., 2013). In recent years, a new study has shown that tissue macrophages are not involved in the early IL-6 response to LPS. CEACAM1, a molecule ubiquitously expressed in the epithelium, neutrophils, activated lymphocytes, negatively regulates the early response of IL-6 to LPS in murine monocytes through the RP105 signaling pathway (Zhang Z. et al., 2019). Therefore, CEACAM1 may be a potential drug target for antipyretic. The present study also sheds light on the issue of the central administration of IL- 6 via PGE2 to induce fever (Harden et al., 2008). Recent studies have further confirmed this view that IL- 6 binds to IL- 6 receptors on brain endothelial cells, and ligand binding induces the expression of the prostaglandin synthase COX-2 through signals involving activator of transcription 3 (STAT3) pathway (Eskilsson et al., 2014).

\section{TNF- $\alpha$}

TNF is a cytokine produced naturally by macrophages in response to bacterial infection or other immune sources. According to its source and structure, it can be divided into two types: TNF- $\alpha$ and TNF- $\beta$. The former is principally produced by macrophages, $\mathrm{T}$ cells, and natural killer cells (Zelová and Hošek, 2013). TNF- $\alpha$ is the first member of cytokine cascade 


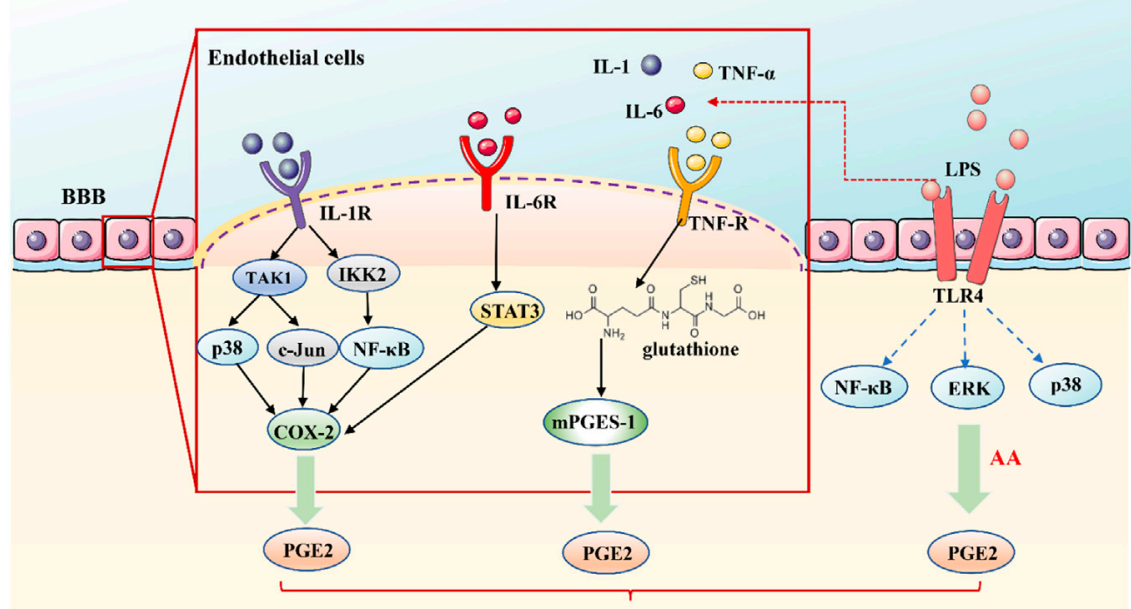

FEVER

FIGURE 1 | The Humoral Transmission Pathway of Fever Signals. Circulating PAMPs, represented by LPS bind to TLR-4 on the fenestrated capillaries in the BBB. Triggering TLR-4 induces the transcription of COX-2 to converted into PGE2, causing fever; pyrogenic cytokines, TNF- $\alpha$, IL-1, and IL-6, play a role outside the brain by activating cytokine receptors located on the CVO, resulting in the release of PGE2 to cause fever.

induced by injection of LPS (Roth and Blatteis, 2014). It has been reported that LPS mediated transcription of TNF- $\alpha$ can be divided into two main signaling pathways. The first proceeds through the NF- $\kappa \mathrm{B}$-inducing kinase route, which regulates the phosphorylation of the inhibitory- $\mathrm{B}$ proteins. The second pathway is mediated by the extracellular signal-regulated kinase and MAPKp38 pathways (Haddad and Land, 2002). Peripheral injection of TNF- $\alpha$ in human and experimental animals can rapidly cause fever (Michie et al., 1988; Roth et al., 1998). Intravenous injection of human recombinant TNF (rhTNF) caused fever in rabbits, which also revealed that the pyrogen potential of rhTNF was associated with an increase in PGE2; the mechanism is related to glutathione. The regulation of TNF- $\alpha$ biosynthesis induced by LPS is redox-sensitive and requires the participation of the glutathione mediated signaling pathway (Wrotek et al., 2015). In the presence of glutathione, it can activate the activity of PGE synthase-1 (mPGES-1), to produce PGE2 (Saha et al., 2005; Thorén and Jakobsson, 2000). A number of researchers also reason that TNF- $\alpha$ induces IL-1 in vivo; therefore, TNF- $\alpha$ and IL-1 may play a synergistic role in fever production; however, no specific mechanism has been reported.

\section{Others}

In addition to the typical pyrogenic cytokines described above, some intrinsic cytokines play a role in fever production (Billiau and Matthys, 2009). Studies have shown that intravenous ET-1 can increase the body temperature of rats. In addition, injection of ET-1 into AH/POA also causes fever, indicating that ET-1 is important for fever response (Zampronio et al., 2015). Leptin is an adipocyte-derived hormone that induced the proinflammatory cytokine IL-1 $\beta$ in the brain, resulting in a prostaglandindependent fever (Wisse et al., 2004). Substance P (SP) belongs to tachykinin family. When SP is antagonized by peptide SP analogues, fever response induced by LPS for guinea pig and rat is blocked, which indicates the role of SP in fever (Pakai et al., 2018).

\section{The Mediator of Fever}

A standard linkage was shared by nearly all pyrogenic cytokines above: the production of PGE2. Previous studies have shown that COX-2 and PGE2 induction is required for fever (Pecchi et al., 2009). In addition to PGE2, other mediators can also induce the generation of fever. Free radicals, glutamate, and metabolic pathway disorders also play a role in fever.

\section{PGE2 in Fever}

The febrile response is characterized by an early rapid phase and a delayed late phase (Blatteis et al., 2004). In some experiments, the pyrogenic cytokines were released later, for example, TNF- $\alpha$ was detected $30 \mathrm{~min}$ after LPS IV injection, while the level of PGE2 increased rapidly after LPS IV injection, and then increased further $40 \mathrm{~min}$ later (Blatteis, 2006; Callery et al., 1991). PGE2 is a lipid-soluble substance that can pass through the blood-brain barrier (BBB), while pyrogenic cytokines are relatively large, lipophobic peptides, and cannot freely pass through the BBB. Therefore, pyrogenic cytokines may not be able to provide rapid fever signals and be involved in maintaining fever (Blatteis et al., 2005). We can speculate that PGE2 is the first to be initiated in the beginning stage of fever, and is the crucial mediator of fever.

Although it seems definite that PGE2 is an essential mediator of fever, it is not certain whether the PGE2 is of the peripheral or central origin. Which stages of febrile pathogenesis are mediated by the peripheral PGE2, and which stages are mediated by the central, these questions require further investigation. The study has shown that the immediate appearance of PGE2 in inferior vena cava plasma after the IV of LPS and puts forward a 


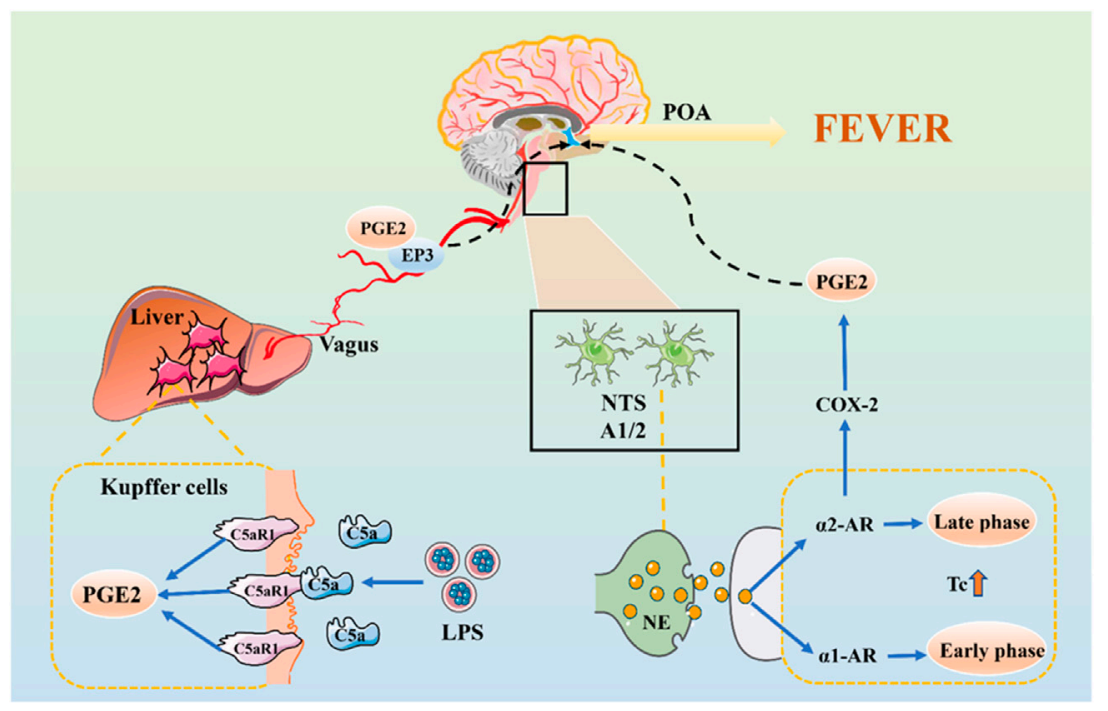

FIGURE 2| The Neural Transmission Pathway of Fever Signals. The initial stage of fever may be mediated by peripheral PGE2, which is released by KC stimulated by LPS-activated C5a and binding to EP3 receptors. PGE2 is transmitted to the NTS via vagal afferents and is further transmitted via the ventral noradrenergic bundle to the POA, wherein NE is released.

hypothesis that LPS-activated complement triggers the release of PGE2 by KC (Perlik et al., 2005). The complement component 5a (C5a) is an essential mediator of the febrile response to LPS ( $\mathrm{Li}$ et al., 2002). C5aR1 is expressed by $\mathrm{KC}$ and rapidly activates COX-1-catalyzed PGE2 production (Schieferdecker et al., 1999; Schieferdecker et al., 2001). PGE receptors have four subtypes, $\mathrm{EP} 1, \mathrm{EP} 2, \mathrm{EP} 3$, and EP4. Studies have shown that EP3 receptors are of great importance in the febrile response. The organum vasculosum of the lamina terminalis (OVLT) and preopticanterior hypothalamic area may be the sites where PGE2 acts on EP3 receptors to generate fever (Oka, 2004). In summary, the initial stage of fever may be mediated by peripheral PGE2, and the rapid transmission of fever signals may depend on neural pathways (see below).

PGE2 is also produced by endothelial cells in the brain and released from the arachidonic acid pathway. This pathway is mediated by the enzymes phospholipase A2 (PLA2), COX-2, and mPGES-1 (Blomqvist and Engblom, 2013; Wilhelms et al., 2014). Brain endothelial cells express IL-1 receptor type 1 (Konsman et al., 2004) and TNF- $\alpha$ receptor p55 (Nadeau and Rivest, 1999). IL-6R is normally absent in the brain endothelial cells, but also induced by inflammation. However, even if there is no membrane-bound IL-6R, soluble IL-6R in blood may participate in IL-6 signal transduction through gp130, a constitutively expressed IL-6 receptor signal sensor in endothelial cells (Vallières and Rivest, 1997). COX-2 and mPGES- 1 are the target genes of NF- $\kappa$ B and STAT3, and the activation of NF- $\kappa$ B or STAT3 in brain endothelial cells is related to COX-2 and mPGES-1 in these cells (Rummel et al., 2006). Previous studies have stated that pyrogenic cytokines can induce the production of COX-2 and mPGES-1 through various signaling pathways, so the PGE2 produced by brain endothelial cells is primarily mediated by the effect of these pyrogenic cytokines. However, the generation of PGE2 by COX-2/mPGES-1 did not coincide with the fever response (Steiner et al., 2006b). Therefore, although peripheral synthesis of PGE2 may occur in initiating the fever, central synthesis of PGE2 may participate in its maintenance.

\section{Oxygen Free Radicals and Glutamate in Fever}

The oxygen free radicals include superoxide anion, hydrogen peroxide, and hydroxyl radical. Dose dependent increase of hydroxyl radical level and core temperature in OVLT induced by LPS or glutamate (Huang et al., 2006). It is suggested that the increase of body temperature caused by LPS or glutamate is related to the increase of hydroxyl radicals in OVLT. Pretreatment with hydroxyl radical scavengers significantly reduced the increase of hydroxyl radicals and fever induced by LPS. Glutamate excessively activation of N-methyl-D-aspartate (NMDA) receptor can produce reactive oxygen species (ROS) in the brain (Yang et al., 1996). After pretreatment with NMDA receptor antagonists, the fever and the increase of hydroxyl radicals in OVLT decreased significantly after LPS injection (Hou et al., 2011). In conclusion, LPS or glutamate may cause excessive accumulation of hydroxyl radicals in peripheral blood and CSF, which can be inhibited by hydroxyl radical scavengers or NMDA receptor antagonists. There is evidence that ROS can activate NF- $\kappa \mathrm{B}$ as a second messenger, leading to over induction of COX-2 (Oh et al., 2004). After LPS injection, the ROS in the hypothalamus can stimulate the activation of NF- $\kappa \mathrm{B}$ and the expression of COX-2, resulting in the excessive production of $\mathrm{NO}$ and PGE2, thus causing fever (Huang et al., 2006). The role of oxygen free radicals and glutamate in a fever not only provides a new theoretical basis for people to understand the mechanism of 
fever but also suggests that anti-free radical injury could be a new way to study the mechanism of fever in the future.

\section{Metabolic Disorders in Fever}

A febrile response is a systemic pathological process. In recent years, metabonomics has been widely used in the study of febrile response to reveal the pathological mechanism of this system response. Three methods were used to establish fever model in rats, and the characteristics of plasma metabolism in febrile rats were studied: the TCM-induced rats with fever, yeast-induced rats with fever, and 2,4-dinitrophenol-induced rats with fever, to further investigate the common potential biomarkers in rats with fever (Liu et al., 2017b). The changes in plasma metabolites showed that amino acid, fatty acid amides, phospholipid, sphingolipid, fatty acid oxidation, and glycerolipid metabolisms; also, bile acid biosynthesis were related to fever. It has been confirmed that tryptophan metabolism is important in the metabolic disorder in the fever response (Gao et al., 2013b). Tryptophan, an essential amino acid, is the precursor of 5-hydroxy tryptamine (5-HT) (Guo et al., 2014). It was reported that the 5-HT in the hypothalamus was positively correlated with fever induced by yeast (Peindaries and Jacob, 1971). The increased level of tryptophan in the febrile rats leads to the enhancement of febrile response may be due to the increased ability of tryptophan to synthesize 5-HT. $\gamma$-aminobutyric acid (GABA) and phosphatidylinositol were also increased in the urine of febrile rats (Gao et al., 2013b). The increase of GABA could lead to an increase of temperature through the pathway of $\mathrm{Na}^{+} / \mathrm{Ca} 2^{+}$-cAMP in the hypothalamus (Myers et al., 1976; Romei et al., 2012). The increased cAMP can inhibit the phosphoinositide signaling system and further lead to the significant increase of phosphatidylinositol. Therefore, the disorder of tryptophan metabolism in the process of fever can increase the synthesis of 5-HT and cAMP, and further induce the generation of fever.

Metabonomics is widely used in finding new biomarkers of diseases and revealing the potential mechanism of clinical drugs. At present, it is mainly based on the biomarkers of three kinds of biological liquid samples, serum, plasma, and urine, to reflect the changes in body metabolism. However, because the BBB can control the transfer of molecules between the brain and blood, it is suggested that the metabonomic methods of serum, plasma, and urine should be combined with the metabonomics methods of the brain to explore the antipyretic mechanism of TCM. The research results of metabonomics have created a foundation for the treatment of fever by TCM from different perspectives. They indicate whether we can take a nutritional supplement for the imbalance of essential amino acids, fatty acids, phospholipids, and other substances as a new way of fever treatment in the future.

\section{TRANSMISSION PATHWAY OF FEVER SIGNALS}

The fever activator stimulates the immune cells to produce the pyrogenic cytokines, which are needed to cause fever through
PGE2. At the same time, other central media, independent of PGE2, will also act on the thermoregulatory center to cause fever. At present, with the study of these fever signals and their role when entering the center, it was concluded that the fever response was ultimately regulated in two ways: the humoral and neural pathways (Zeisberger, 1999).

\section{The Humoral Transmission Pathway of Fever Signals}

A classical theory of fever signal transmission is the theory of the humoral transmission pathway. Fever signals are carried by PAMPs or by pyrogenic cytokines in this pathway (Figure 1) (Ogoina, 2011). It is known that circulating PAMPs represented by LPS bind to TLR-4, which is located in the fenestrated capillaries of the circum ventricular organ in the BBB. Triggering TLR- 4 induces the transcription of COX-2 via NF$\kappa \mathrm{B}, \mathrm{MAPKp} 38$, and extracellular signal-regulated kinases (ERK1/ 2).Also cPLA2 phosphorylation and arachidonic acid mobilization, via MAPK or Mitogen- and stress-activated kinases (MSK1), which is, in turn, converted into PGE2 by COX-2 and released into the cell membrane (Salvi et al., 2016); which through the BBB, then activate the thermal neurons in the front of the hypothalamus, causing fever (Steiner et al., 2006a; Turrin and Rivest, 2004).

According to the classical concept, exogenous pyrogens stimulate peripheral mononuclear phagocytes to produce pyrogenic cytokines, principally TNF- $\alpha$, IL-1, and IL-6, which are transported from the blood to the brain (Blatteis, 2006; Blatteis et al., 1998). Pyrogenic cytokines are unable to enter the center to stimulate the brain structures through the BBB (Rothwell et al., 1996). At present, there are several opinions on how pyrogenic cytokines are involved in the brain. Pyrogenic cytokines may directly penetrate the sensory circumventricular organs (CVOs) without BBB. Pyrogenic cytokines bind to and activate cytokines receptors on the fenestrated capillaries of the CVO which act outside the brain, leading to the release of PGE2 (Conti et al., 2004; Ogoina, 2011). Vascular endothelial cells and perivascular cells within the entire brain, have been shown to secrete IL6 , PGE2, and other mediators into the brain parenchyma after being stimulated by inflammation in the lumen (blood) side (Blatteis et al., 2000; Roth and Blatteis, 2014; Schiltz and Sawchenko, 2003). In the humoral pathway of fever signal transmission, pyrogenic cytokines can enter the brain directly through the tissue lacking $\mathrm{BBB}$ to cause fever or to release PGE2 outside the brain indirectly or stimulate the $\mathrm{BBB}$ cells to deliver fever medium to the brain's endocrine system and cause fever.

Due to initial detection of pyrogenic cytokines in the blood does not coincide with the fever caused by IV LPS, the hypothesis of the humoral pathway is not enough to explain the whole process of fever signal transmission. Therefore, an accelerated pathway of fever signal transmission, the neural pathway, has been proposed. The neural pathway, as a supplementary pathway of the humoral pathway, functions in the conduction of fever 


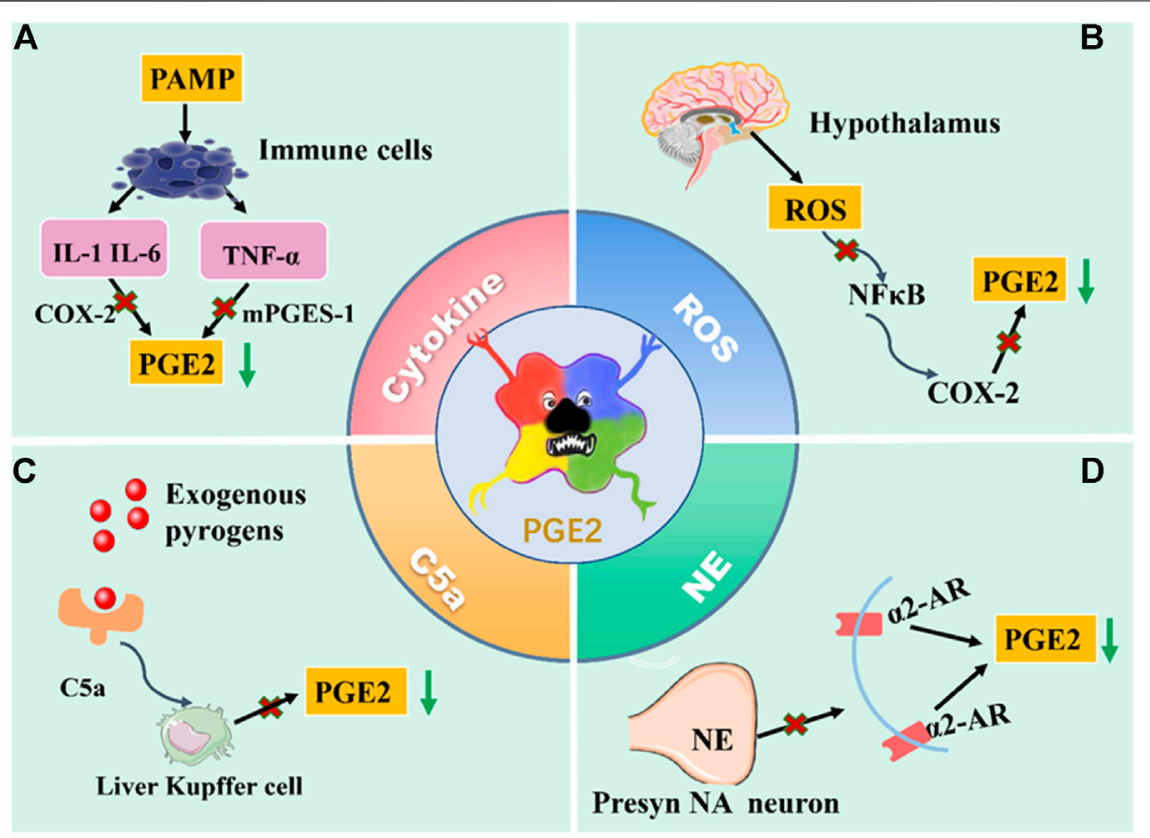

FIGURE 3 | The production way of PGE2. (A) PAMPs induces pyrogenic cytokines through pattern recognition receptors such as TLR on immune cells. IL1and IL-6 can activate COX-2 to produce PGE2; TNF- $\alpha$ activates the mPGES-1 and produces PGE2. (B) In the fever state, the overproduction of ROS in the hypothalamus stimulates the activation of NF- $\mathrm{KB}$ and expression of COX-2, leading to the generation of PGE2. (C) LPS-activated complement can rapidly trigger KC to activate COX-1 to catalyze PGE2 production. (D) NE induces the production of COX-2/mPGES-1-dependent PGE2 in the POA via an a2-AR-mediated mechanism. Above, the antipyretic effect was achieved by blocking the production pathway of PGE2 and reducing the content of PGE2.

signals in coordination with the humoral pathway. The conduction process of the two pathways is complex, so the mechanism of their synergistic effect requires further study.

\section{The Neural Transmission Pathway of Fever Signals}

The activation of the neural pathway is believed to be another mechanism for fever (Figure 2). The idea of a neural transmission pathway concerned with fever emerged decades ago. In 1987, Morimoto speculated that peripheral nerves were involved in the development of fever (Morimoto et al., 1987). The messages, utilizing nerve fibers, have the advantages of rapid transmission speed and not being affected by the impedance of the BBB. The rapidity of neural communication between the immune system and the brain seems to be crucial at the beginning of fever (Romanovsky et al., 2000).

Previous studies have shown that bilateral truncal subdiaphragmatic vagotomy or intraperitoneal injection of low doses of capsaicin can desensitize the abdominal sensory nerve and inhibit the fever caused by IV LPS in rats (Romanovsky et al., 1997; Székely et al., 2000). The anterior and posterior branches of the vagus nerve are divided into five main branches under the diaphragm. We have shown that the selective hepatic branch vagotomy plays an important role in the early febrile phase (Simons et al., 1998). The circulating LPS activates KC to produce a factor that stimulates cognate receptors on hepatic vagal afferents, and quickly transmits its fever information to POA (Blatteis, 2006). In the early stage of fever, it may be mediated by peripheral PGE2, which is released by $\mathrm{KC}$ stimulated by LPS-activated C5a and binding to EP3 receptors on sensory hepatic vagal afferents.

There may be another mechanism for nerve conduction of fever signals. LPS induce c-fos expression in the nucleus of the solitary tract (NTS) (Wan et al., 1994). PGE2 is produced in the peripheral, introduced into the NTS through vagal afferents and is further transmitted to POA through the ventral noradrenergic bundle, in which norepinephrine (NE) is released (Roth and Blatteis, 2014). The role of the central noradrenergic system in thermoregulation has also been confirmed. NE induces two differentially mediated temperature rises: the first develops promptly and is mediated by the a1-adrenergic receptor ( $\alpha 1$ AR), but not by PGE2 (Roth and Blatteis, 2014). The second is mediated by $\alpha 2-\mathrm{AR}$ and NE induces the production of COX-2/ mPGES-1-dependent PGE2 in the POA via an a2-AR-mediated mechanism which is significantly later than the first (Blatteis, 2006). PGE2 also enhances the production of cAMP of hypothalamic cells, which can change the temperature set-point.

Generally speaking, fever is the result of complex and periodic interactions between the fever medium and the body. The mechanism of its occurrence is complex. From the material basis of fever and the transmission of fever signals, PGE2 is the vital medium of fever, whether infectious or noninfectious fever. Its means of production are 1) invasion of exogenous pyrogen to the host triggers a series of immune responses through PAMPs. PAMPs induces pyrogenic cytokines (IL-1, IL-6, and TNF- $\alpha$ ) through pattern recognition receptors such as TLR on immune cells. IL-1 can activate MAPKp38 and c-Jun by TAK1 to induce COX-2 and produce PGE2; it can also induce 
COX-2 and PGE2 by activating the NF- $\kappa$ B pathway. After binding IL-6 with IL-6R on brain endothelial cells, COX-2 expression can be induced by intracellular signaling of the STAT3 pathway to produce PGE2. TNF- $\alpha$ activates the mPGES-1 and produces PGE2 under the glutathione mediated signal pathway. 2) In the fever state, the overproduction of ROS in the hypothalamus stimulates the activation of NF- $\kappa B$ and expression of COX-2, leading to the generation of PGE2. 3) LPS-activated complement can rapidly trigger $\mathrm{KC}$ to activate COX-1 to catalyze PGE2 production. 4) NE induces the production of COX-2/mPGES-1-dependent PGE2 in the POA via an a2-AR-mediated mechanism (as shown in Figure 3).

The humoral pathway transmits the first two kinds of fever signals; the neural pathways mediate the rest. The above understanding of the fever mechanism also broadens a new way of thinking for antipyretic. The antipyretic effect can be achieved by inhibiting the production of PGE2 in various ways and blocking its role in the fever pathway. Recent research data on the fever medium indicates that some endogenous mediums may cause fever. These studies show that in addition to PGE2, the mediators produced by the center also participate in the fever response. At present, the corticotropin-releasing factor, endothelin, and macrophage inflammatory protein one are the most studied central agents of fever. However, whether the antipyretic effect is independent of PGE2 is still controversial. Therefore, the antipyretic mechanism needs further study.

\section{SINGLE CHINESE HERBAL MEDICINES IN THE TREATMENT OF FEVER}

\section{Bupleuri Radix}

Bupleuri Radix (BR), called Chaihu in Chinese, is the dried roots of Bupleurum chinense DC and Bupleurum scorzonerifolium Willd. The compounds of BR include essential oils, triterpenoid saponins, polyacetylenes, flavonoids, lignans, fatty acids, and sterols (Yang et al., 2017). Jin et al. (2014) researched the effect of BR water extract, BR saponin extract, and BR essential oil extract on the fever model of rats via subcutaneous injection of a yeast suspension. It was observed that the three extracts had a good antipyretic effect. Chen et al. (2010) extracted the essential oil from BR to prepare the gel and sprayed it into the nasal cavity of febrile rabbits that had undergone IV injected Escherichia coli endotoxin. The results showed that the essential oil of BR could play an antipyretic effect on the rabbit's fever by decreasing the concentration of cAMP in the cerebrospinal fluid. One study demonstrated that intracerebroventricular injection of saikosaponin A (SSA) reduces the core temperature of rats with fever caused by IL$1 \beta$ after $30 \mathrm{~min}$. At the same time, the content of cAMP in serum and protein kinase A (PKA) in the cytoplasm was significantly lower than those in the model group. The results showed that SSA could be used as an antipyretic by reducing cAMP secretion and PKA activity in the hypothalamus (Sun et al., 2016). The study demonstrated that SSA can significantly inhibit the expression of TNF- $\alpha$, IL- $1 \beta$, and IL- 6 ; it also inhibits the activation of the NF$\kappa \mathrm{B}$ signaling pathway by suppressing the phosphorylation of

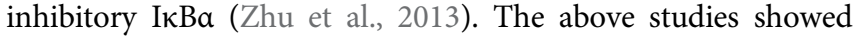
that BR could play an antipyretic role by inhibiting the secretion of cAMP, the expression of pyrogenic cytokines, the activity of $\mathrm{PKA}$, and the activation of the NF- $\mathrm{B}$ signaling pathway.

\section{Scutellariae Radix}

Scutellariae Radix (SR), known as Huangqin in Chinese, is the dried root of the Labiatae plant Scutellariae baicalensis Georgi (Bruno et al., 2002). Flavonoids, phenylethanoid glycosides, iridoid glycosides, alkaloids, phytosterols, and polysaccharides are the main compounds of SR (Li et al., 2011). SR has an antipyretic effect in the clinical setting. In recent years, the antipyretic mechanism of SR and its components have been studied intensely. The results show that baicalin and baicalein are main active components of SR for reducing fever (Yang and Meng, 2009). The body temperature of rats with fever-induced by yeast decreased significantly after the administration of baicalin by gavage. The contents of IL- 6 , IL- $1 \beta$, and TNF- $\alpha$ in serum, hypothalamus, and CSF of rats decreased correspondingly, indicating that baicalin has an antipyretic effect by reducing the content of pyrogenic cytokines (Li and Ge, 2010). Baicalin was used to treat rats with fever induced by intraperitoneal injection of LPS. The results showed that baicalin significantly reduced the body temperatures of the fever rats. The mechanism may be that baicalin can inhibit the up-regulation of TLR4 mRNA and protein expression regulated by LPS, downregulate NF- $\kappa B$ activation and decrease the expression of TNF- $\alpha$, IL- $1 \beta$ protein (Ye et al., 2015). Baicalin can inhibit the fever response induced by LPS and the excessive production of glutamate and hydroxyl radicals in the hypothalamus caused by central administration of TNF- $\alpha$. These results suggest that the antipyretic effect of baicalin may be achieved by inhibiting the MNDA receptor-dependent hydroxyl radical pathways in the hypothalamus and circulating TNF- $\alpha$ accumulation during LPSinduced fever (Tsai et al., 2006). Nakahata et al. (1998) found that $\mathrm{Ca}^{+}$ionophore A23187 caused phosphorylation of MAPK, resulting in the activation of cytosolic phospholipase A2 (cPLA2), baicalein reduces the A23187 induced PGE2 release by inhibition of AA liberation through the inhibition of the MAPK-cPLA2 pathway. Baicalein inhibit the expression of COX-2 induced by LPS in Raw 264.7 cells, through blockading $\mathrm{C} / \mathrm{EBPb} \mathrm{DNA}$ binding to the COX-2 promoter, thereby inhibiting the expression of COX-2 and the production of PGE2 (Woo et al., 2006). In conclusion, SR can play an antipyretic role by inhibiting the release of pyrogenic cytokines and PGE2, the activation of NF- $\kappa \mathrm{B}$, and the excessive production of hydroxyl radicals.

\section{Chuanxiong Rhizome}

Chuanxiong Rhizome (CX), also known as Chuanxiong in Chinese, the dried rhizome of Conioselinum anthriscoides 'Chuanxiong' (syn. Ligusticum chuanxiong Hort) The main effective components of CX are phthalides, terpenes, polysaccharides, alkaloids, and essential oil (Chen et al., 2018). A large number of studies have shown that the CX essential oil has an antipyretic effect. The body temperature of the rats with fever caused by subcutaneous injection of $20 \%$ yeast suspension was significantly decreased after CX essential oil administration; 


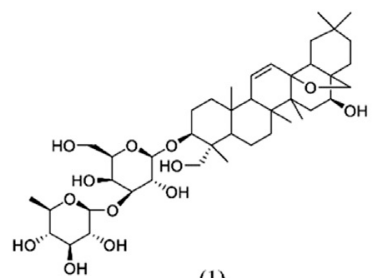

(1)<smiles>O=C(O)C1OC(Oc2cc3oc(-c4ccccc4)cc(=O)c3c(O)c2O)C(O)C(O)C1O</smiles>

(2)<smiles>O=c1cc(-c2ccccc2)oc2cc(O)c(O)c(O)c12</smiles>

(3)<smiles>CCC/C=C1/OC(=O)C2=C1CCC=C2</smiles>

(4)<smiles>CCCCC1OC(=O)C2=C1CCC=C2</smiles>

(5)<smiles>O=C/C=C/c1ccccc1</smiles>

(6)<smiles>CC1CC(OC2OC(OCCc3ccc(O)c(O)c3)C(O)C(O)C2OC(=O)/C=C/c2ccc(O)c(O)c2)C(O)C(O)[C@H]1O</smiles>

(7)<smiles>CNC(C)C(O)c1ccccc1</smiles>

(8)<smiles>O=c1c(-c2ccc(O)cc2)coc2c(O)c(O)ccc12</smiles>

(12)

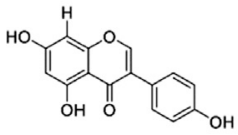

(16)<smiles>COC(=O)C1=COC2OC3OC(CO)[C@@H](O)[C@H](O)C3C(CO)=CC2C1O</smiles>

(9)<smiles>COc1ccc2c(c1)OCC(c1ccc(O)cc1)C2=O</smiles>

(13)

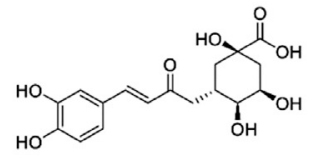

(17)<smiles></smiles>

(10)

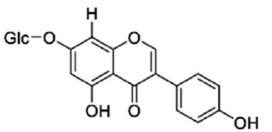

(14)<smiles>C=C1CC[C@]2(O)[C@@H](CC[C@@H](O)[C@@]2(C)O)[C@@H]1/C=C/C1=CCOC1=O</smiles>

(11)

FIGURE 4 | Chemical structures of e phytochemicals that possess antipyretic activity (1)Saikosaponin A; (2) Baicalin; (3) Baicalein; (4) Z-ligustilide; (5) Senkyunolide A; (6) Cinnamaldehyde; (7) Forsythoside A; (8) Ephedrine; (9) Geniposide; (10) Andrographolide; (11) 14-deoxy-11,12-didehydroandrographolide; (12) Puerarin; (13) Daidzin; (14) Genistin; (15) Daidzein; (16) Genistein; (17) Chlorogenic acid.

TABLE 2 | The single Chinese herbal medicine of antipyretic.

Chinese herbal medicine

Scientific name

Bupleuri radix

Scutellariae radix

Chuanxiong rhizome

Conioselinum anthriscoides 'Chuanxiong' (syn. Ligusticum chuanxiong Hort)

Cinnamomi ramulus

Cinnamomum cassia (L.) J.Presl

Forsythiae Fructus

Forsythia suspensa (Thunb.) Vahl

\section{Bioactive \\ components} oilForsythoside a (7)

Essential

oilsaikosaponin a (1)

Baicalin (2)

Baicalein (3)

Z-ligustilide (4) senkyunolide a (5)

Cinnamaldehyde (6)

$$
\text { oilForsythoside a (7) }
$$

\section{Mechanisms}

Decrease the concentration of CAMP; Reduce CAMP secretion and PKA activity in the hypothalamus; Inhibit the expression of TNF- $\alpha$, IL-1 $\beta$, IL- 6 and the activation of the $\mathrm{NF}-\mathrm{kB}$ signaling pathway

Inhibit the upregulation of TLR4 mRNA; Downregulated NF-kB activation with simultaneous decreases in TNF- $\alpha$ and IL-1 $\beta$ protein expression; Suppress glutamate and hydroxyl radicals in the hypothalamus; Inhibit the expression of COX-2 and PGE2 Inhibit the expression of COX-2 and PGE2; Reduce the content of CAMP in the hypothalamus; Change of monoamine neurotransmitter content in the center; Suppressive effects on TNF- $\alpha$-mediated NF-kB activation Up-regulated the expression of TRPV1 in DRG neurons; Reduce the activity of COX-2 in brain endothelial cells and the content of PGE2 in the hypothalamus of febrile rats Reduce the content of CAMP in the hypothalamus; Suppress TRPV1 expression and activation, inhibiting MAPKs activation of the hypothalamus and DRG Inhibit TNF- $\alpha$ and NF-kB through blockade of the LPS/TLR4 signaling pathways Inhibit the synthesis of PGE2 by inhibiting the activity of COX-2; Inhibit EP3 expression in $\mathrm{POAH}$ 
TABLE 3 | The other single Chinese herbal medicine of antipyretic.

\begin{tabular}{|c|c|c|c|c|c|c|c|}
\hline $\begin{array}{l}\text { Chinese } \\
\text { herbal } \\
\text { medicine }\end{array}$ & Scientific name & Bioactive components & Model & $\begin{array}{l}\text { Drug delivery } \\
\text { cycle }\end{array}$ & Mechanisms & $\begin{array}{l}\text { The species } \\
\text { investigated }\end{array}$ & References \\
\hline $\begin{array}{l}\text { Ephedrae } \\
\text { Herba }\end{array}$ & $\begin{array}{l}\text { Ephedra sinica Stapf, } \\
\text { Ephedra intermedia } \\
\text { Schrenk et C. A. Mey and } \\
\text { Ephedra equisetina } \\
\text { Bunge. }\end{array}$ & Ephedrine (8) & $\begin{array}{l}\text { Subcutaneous injection } \\
\text { of } 20 \% \text { yeast water } \\
\text { suspension }(10 \mathrm{ml} / \mathrm{kg}) \\
\text { to induce fever }\end{array}$ & $\begin{array}{l}\text { Ephedrae Herba extracts were } \\
\text { administered } 8.1 \mathrm{~g} / \mathrm{kg}\end{array}$ & $\begin{array}{l}\text { Reduce the level of } 5 \text { - } \\
\text { hydroxytryptamine and NE in } \\
\text { the hypothalamus }\end{array}$ & $\begin{array}{l}\text { Fifty Wistar rats } \\
\text { (weighing } 200 \pm 20 \mathrm{~g} \text { ) }\end{array}$ & $\begin{array}{l}\text { Wang et al. } \\
\text { (2018a) }\end{array}$ \\
\hline $\begin{array}{l}\text { Gypsum } \\
\text { Fibrosum }\end{array}$ & - & - & $\begin{array}{l}\text { Subcutaneous injection } \\
\text { of } 15 \% \text { yeast } \\
\text { suspension }(10 \mathrm{ml} / \mathrm{kg}) \\
\text { to induce fever }\end{array}$ & $\begin{array}{l}\text { Intragastric administration of } \\
\text { Gypsum suspension for } 7 \text { days } \\
(10 \mathrm{~g} / \mathrm{kg})\end{array}$ & Reduce the synthesis of PGE2 & $\begin{array}{l}\text { Aged SD rats } \\
\text { (weighing200-250 g) }\end{array}$ & $\begin{array}{l}\text { TangZhishu } \\
\text { and Bing } \\
\text { (2012) }\end{array}$ \\
\hline $\begin{array}{l}\text { Gardeniae } \\
\text { Fructus }\end{array}$ & $\begin{array}{l}\text { Gardenia jasminoides } \\
\text { J.Ellis }\end{array}$ & Geniposide (9) & $\begin{array}{l}15 \% \text { saline suspension } \\
\text { of yeast was injected in } \\
\text { the back of rats } \\
(10 \mathrm{ml} / \mathrm{kg})\end{array}$ & $\begin{array}{l}\text { Administered with Gardeniae } \\
\text { Fructus } \\
\text { at } 4.5 \mathrm{~g} / \mathrm{kg}(10 \mathrm{~m} / \mathrm{kg})\end{array}$ & $\begin{array}{l}\text { Reduce the expression of IL-6 } \\
\text { and TNF- } \alpha \text {; Reduce the } \\
\text { production of PGE2 }\end{array}$ & $\begin{array}{l}\text { Male SD rats (weighing } \\
170 \pm 10 \mathrm{~g} \text { ) }\end{array}$ & $\begin{array}{l}\text { Zhang X. et al } \\
\text { (2019) }\end{array}$ \\
\hline Bubali Cornu & Bubalus bubalis Linnaeus & - & $\begin{array}{l}\text { Fever caused by } \\
\text { subcutaneous injection } \\
\text { of } 20 \% \text { yeast }(10 \mathrm{ml} / \mathrm{kg})\end{array}$ & $\begin{array}{l}400 \mathrm{mg} / \mathrm{kg} \text { Bubali Cornu powder } \\
\text { extract was administrated orally } \\
\text { with a dosage of } 10 \mathrm{ml} / \mathrm{kg}\end{array}$ & $\begin{array}{l}\text { Change the metabolism of uric } \\
\text { acid and cysteine; enhance } \\
\text { the activity of antioxidant } \\
\text { enzymes; reduce the level of } \\
\text { TNF - } \alpha \text {; reduce the ROS } \\
\text { production and PGE2 } \\
\text { synthesis }\end{array}$ & $\begin{array}{l}\text { Aged SD rats } \\
\text { (weighing } 200 \pm 20 \mathrm{~g} \text { ) }\end{array}$ & Liu et al. (2016) \\
\hline $\begin{array}{l}\text { Houttuyniae } \\
\text { Herba }\end{array}$ & $\begin{array}{l}\text { Houttuynia cordata } \\
\text { Thunb }\end{array}$ & - & $\begin{array}{l}\text { Fever caused by } \\
\text { subcutaneous injection } \\
\text { of } 15 \% \text { yeast } \\
\text { suspension }(10 \mathrm{ml} / \mathrm{kg})\end{array}$ & $\begin{array}{l}\text { Three hours after the } \\
\text { establishment of the model, } 20 \text {, } \\
\text { 10, and } 5 \mathrm{ml} / \mathrm{kg} \text { were } \\
\text { administrated intravenously in the } \\
\text { high, middle and low dose groups }\end{array}$ & $\begin{array}{l}\text { Inhibit the production of } 1 \mathrm{~L}-1 \text {, } \\
\text { TNF- } \alpha \text {, and the expression of } \\
\text { PGE2 }\end{array}$ & Aged male SD rats & $\begin{array}{l}\text { Zhang et al. } \\
\text { (2010) }\end{array}$ \\
\hline $\begin{array}{l}\text { Andrographis } \\
\text { Herba }\end{array}$ & $\begin{array}{l}\text { Andrographis paniculata } \\
\text { (Burm. f.) Nees }\end{array}$ & $\begin{array}{l}\text { Andrographolide (10)14- } \\
\text { deoxy11,12- } \\
\text { didehydroandrographolide (11) }\end{array}$ & $\begin{array}{l}\text { Rats were injected } \\
\text { subcutaneously with } \\
\text { yeast }(0.135 \mathrm{~g} / \mathrm{kg})\end{array}$ & $\begin{array}{l}\text { Two hours after yeast } \\
\text { injection, } 4 \mathrm{mg} / \mathrm{kg} \text { of andrographis } \\
\text { Herba extracts were } \\
\text { injectedlntraperitoneally }\end{array}$ & $\begin{array}{l}\text { Inhibit the expression of NF- } \\
\text { kB, reducing the expression } \\
\text { COX-2 and the level of PGE2 }\end{array}$ & SD rats & $\begin{array}{l}\text { Suebsasana } \\
\text { et al. (2009) }\end{array}$ \\
\hline $\begin{array}{l}\text { Puerariae } \\
\text { Lobatae radix }\end{array}$ & $\begin{array}{l}\text { Pueraria montana var. } \\
\text { lobata (Willd.) Maesen \& } \\
\text { S.M.Almeida ex Sanjappa } \\
\text { \& Predeep (syn. Pueraria } \\
\text { lobata (Willd.) Ohw) }\end{array}$ & $\begin{array}{l}\text { Puerarin (12) daidzin (13) } \\
\text { Daidzein (14)Genistin (15) } \\
\text { Genistein (16) }\end{array}$ & $\begin{array}{l}\text { Fever caused by } \\
\text { subcutaneous injection } \\
\text { of LPS ( } 50 \mathrm{mg} / \mathrm{kg} \text { ) }\end{array}$ & $\begin{array}{l}\text { The experimental groups received } \\
50 \text { and } 100 \mathrm{mg} / \mathrm{kg} \text { of pueraria } \\
\text { extract }\end{array}$ & $\begin{array}{l}\text { Inhibit cyclooxygenase; inhibit } \\
\text { PGE2 release From mouse } \\
\text { peritoneal macrophages } \\
\text { in vitro }\end{array}$ & $\begin{array}{l}\text { Male mice (weighing } \\
22-26 \mathrm{~g} \text { ) }\end{array}$ & $\begin{array}{l}\text { Yasuda et al. } \\
\text { (2005) }\end{array}$ \\
\hline
\end{tabular}


TABLE 4 | Chinese Patent Medicines and Complex Prescriptions of antipyretic.

\begin{tabular}{|c|c|c|c|c|c|c|c|}
\hline $\begin{array}{l}\text { Chinese } \\
\text { patent } \\
\text { medicine and } \\
\text { complex } \\
\text { prescriptions }\end{array}$ & Components & Scientific name & Model & $\begin{array}{l}\text { Drug delivery } \\
\text { cycle }\end{array}$ & Mechanisms & $\begin{array}{l}\text { The species } \\
\text { investigated }\end{array}$ & References \\
\hline $\begin{array}{l}\text { Jinxin oral liquid } \\
\text { (JXOL) }\end{array}$ & $\begin{array}{l}\text { Ephedra sinica, } \\
\text { Descurain Semen, } \\
\text { Mori Cortex, } \\
\text { Armeniacae } \\
\text { Semen Amarum, } \\
\text { Gypsum Ustum, } \\
\text { Peucedani Radix, } \\
\text { Scutellariae Radix, } \\
\text { Polygoni Cuspidati } \\
\text { Rhizoma et Radix }\end{array}$ & $\begin{array}{l}\text { Ephedra sinica Stapf, } \\
\text { Descurainia sophia (L.) } \\
\text { Webb ex Prantl, } \\
\text { Morus alba L., } \\
\text { Prunus armeniaca L, } \\
\text { Gypsum Ustum, } \\
\text { Scutellaria baicalensis } \\
\text { Georgi, } \\
\text { Reynoutria japonica Houtt }\end{array}$ & $\begin{array}{l}\text { Fever caused by } \\
\text { subcutaneous } \\
\text { injection of } 20 \% \\
\text { yeast }(15 \mathrm{ml} / \mathrm{kg} \text { ) }\end{array}$ & $\begin{array}{l}\text { Subcutaneous } \\
\text { injection of } \\
7.02 \mathrm{~g} / \mathrm{kg} \mathrm{JXOL}\end{array}$ & $\begin{array}{l}\text { Reduce the production of } \\
\text { IL-1 } \beta \text {, PGE2 and the level } \\
\text { of quinolinic acid and } \\
\text { pantothenic acid; regulate } \\
\text { the metabolism level of 3- } \\
\text { phosphoglycerate, } \\
\text { pyruvate and other } \\
\text { metabolites }\end{array}$ & $\begin{array}{l}\text { Male SD rats } \\
\text { (weighing } \\
80 \pm 20 \mathrm{~g} \text { ) }\end{array}$ & $\begin{array}{l}\text { Qian et al. } \\
\text { (2019) }\end{array}$ \\
\hline $\begin{array}{l}\text { Yin Qiao } \\
\text { San (YQS) }\end{array}$ & $\begin{array}{l}\text { Lonicera Japonica } \\
\text { Flos, } \\
\text { Lophatheri Herba, } \\
\text { Forsythiae Fructus, } \\
\text { Platycodonis } \\
\text { Radix, } \\
\text { Sojae Semen } \\
\text { Praeparatum, Arctii } \\
\text { Fructus, } \\
\text { Menthae } \\
\text { Haplocalycis } \\
\text { Herba, } \\
\text { Schizonepetae } \\
\text { Herba, } \\
\text { Phyllostachys } \\
\text { Rhizoma, } \\
\text { Glycyrrhizae Radix } \\
\text { et Rhizoma }\end{array}$ & $\begin{array}{l}\text { Lonicera japonica Thunb, } \\
\text { Lophatherum gracile } \\
\text { Brongn, } \\
\text { Forsythia suspensa (Thunb.) } \\
\text { Vahl, } \\
\text { Platycodon grandiflorus } \\
\text { (Jacq.) A.DC., } \\
\text { Glycine max (L.) Merr., } \\
\text { Arctium lappa L., } \\
\text { Mentha canadensis L., } \\
\text { Nepeta tenuifolia Benth., } \\
\text { Phragmites australis subsp. } \\
\text { Australis, } \\
\text { Glycyrrhiza uralensis Fisch. } \\
\text { ex DC. }\end{array}$ & $\begin{array}{l}\text { Subcutaneous } \\
\text { injection of } 20 \% \\
\text { yeast }(20 \mathrm{ml} / \mathrm{kg} \text { ) to } \\
\text { induce fever }\end{array}$ & $\begin{array}{l}\text { Different doses of } \\
\text { YQS solution were } \\
\text { respectively gavage } \\
\text { administration in } \\
\text { fever rats }\end{array}$ & $\begin{array}{l}\text { Reduce the cAMP level of } \\
\text { the hypothalamus }\end{array}$ & $\begin{array}{l}\text { Male SD rats } \\
\text { (weighing } \\
200 \pm 20 \mathrm{~g} \text { ) }\end{array}$ & $\begin{array}{l}\text { Huang and } \\
\text { Chang (2016) }\end{array}$ \\
\hline $\begin{array}{l}\text { Hao Jia Xu Re } \\
\text { Qing } \\
\text { Granules (HJ) }\end{array}$ & $\begin{array}{l}\text { Artemisiae Annuae } \\
\text { Herba, } \\
\text { Glycyrrhizae Radix } \\
\text { et Rhizoma } \\
\text { Trionycis Carapax, } \\
\text { Rehmanniae } \\
\text { Radix, } \\
\text { Dendrobii caulis, } \\
\text { Anemarrhenae } \\
\text { rhizoma, } \\
\text { Moutan cortex, } \\
\text { Puerariae Lobatae } \\
\text { Radix, }\end{array}$ & $\begin{array}{l}\text { Artemisia annua L., } \\
\text { Glycyrrhiza uralensis Fisch. } \\
\text { ex DC., } \\
\text { Trionyx sinensis Wiegmann, } \\
\text { Rehmannia glutinosa } \\
\text { (Gaertn.) DC., } \\
\text { Dendrobium nobile Lindl., } \\
\text { Anemarrhena asphodeloides } \\
\text { Bunge, } \\
\text { Paeonia suffruticosa } \\
\text { Andrews, } \\
\text { Pueraria montana var. } \\
\text { lobata (Willd.) Maesen \& } \\
\text { S.M.Almeida ex Sanjappa \& } \\
\text { Predeep }\end{array}$ & $\begin{array}{l}\text { Rats were } \\
\text { subcutaneously } \\
\text { injected with } \\
10 \mathrm{mg} / \mathrm{kg} \text { of } 10 \% \\
\text { yeast suspension }\end{array}$ & $\begin{array}{l}1.44 \mathrm{~g} / \mathrm{kg} \text {, } \\
0.72 \mathrm{~g} / \mathrm{kg} \text {, } \\
0.36 \mathrm{~g} / \mathrm{kg} \text { of } \mathrm{HJ} \\
\text { were given by } \\
\text { gavage after being } \\
\text { injected with yeast }\end{array}$ & $\begin{array}{l}\text { Inhibit the tryptophan } \\
\text { metabolism; Reduce the } \\
\text { level of } 5-\mathrm{HT}\end{array}$ & $\begin{array}{l}\text { SD rats } \\
\text { (weighing } \\
200 \pm 20 \text { ) }\end{array}$ & $\begin{array}{l}\text { Yu et al. } \\
(2018)\end{array}$ \\
\hline $\begin{array}{l}\text { Reduning } \\
\text { injection (RDN) }\end{array}$ & $\begin{array}{l}\text { Artemisiae Annuae } \\
\text { Herba, Lonicera } \\
\text { Japonica Flos, } \\
\text { Gardeniae Fructus }\end{array}$ & $\begin{array}{l}\text { Artemisia annua L., } \\
\text { Lonicera japonica Thunb, } \\
\text { Gardenia jasminoides J.Ellis }\end{array}$ & $\begin{array}{l}\text { Rats were } \\
\text { subcutaneously } \\
\text { injected with } 5 \mathrm{ml} / \mathrm{kg} \\
\text { of } 20 \% \text { yeast } \\
\text { suspension }\end{array}$ & $\begin{array}{l}\text { Rats were I.V.with } \\
6 \mathrm{ml} / \mathrm{kg} \text { RDN }\end{array}$ & $\begin{array}{l}\text { Reduce the level of IL- } 1 \beta \text {, } \\
\mathrm{IL}-6, \mathrm{PGE} 2 \text {, TNF- } \alpha \text { and } \\
\text { CAMP in febrile rats; } \\
\text { Change the regulation of } \\
\text { amino acid metabolism, } \\
\text { lipid metabolism and } \\
\text { energy metabolism }\end{array}$ & $\begin{array}{l}\text { Male SD rats } \\
\text { (weighing180- } \\
220 \mathrm{~g} \text { ) }\end{array}$ & $\begin{array}{l}\text { Gao et al. } \\
(2020)\end{array}$ \\
\hline $\begin{array}{l}\text { Gegen Qinlian } \\
\text { decoction } \\
\text { (GQLD) }\end{array}$ & $\begin{array}{l}\text { Puerariae lobatae } \\
\text { Radix, } \\
\text { Scutellariae Radix, } \\
\text { Coptidis Rhizoma, } \\
\text { Glycyrrhizae Radix } \\
\text { et Rhizoma } \\
\text { Praeparata Cum } \\
\text { Melle }\end{array}$ & $\begin{array}{l}\text { Pueraria montana var. } \\
\text { lobata (Willd.) Maesen \& } \\
\text { S.M.Almeida ex Sanjappa \& } \\
\text { Predeep, } \\
\text { Scutellaria baicalensis } \\
\text { Georgi, } \\
\text { Coptis teeta Wall., } \\
\text { Glycyrrhiza glabra L., }\end{array}$ & $\begin{array}{l}\text { Rats were } \\
\text { subcutaneously } \\
\text { injected with } \\
10 \mathrm{ml} / \mathrm{kg} \text { of } 20 \% \\
\text { yeast suspension }\end{array}$ & $\begin{array}{l}\text { Rats were orally } \\
\text { administered with } \\
\text { GQLD }(1.728 \mathrm{~g} / \mathrm{kg})\end{array}$ & $\begin{array}{l}\text { Regulate the metabolisms } \\
\text { of phospholipid, } \\
\text { sphingolipid, fatty acid } \\
\text { oxidation, fatty acid } \\
\text { amides, amino acid and } \\
\text { glycerolipid in vivo }\end{array}$ & $\begin{array}{l}\text { Male Wistar rats } \\
\text { weighing } \\
(240 \pm 20 \mathrm{~g})\end{array}$ & $\begin{array}{l}\text { Liu et al. } \\
\text { (2019b) }\end{array}$ \\
\hline $\begin{array}{l}\text { Bai-Hu } \\
\text { decoction } \\
\text { (BHD) }\end{array}$ & $\begin{array}{l}\text { Gypsum Ustum, } \\
\text { Anemarrhena } \\
\text { Rhizoma, } \\
\text { Glycyrrhizae Radix } \\
\text { et Rhizoma } \\
\text { Praeparata Cum } \\
\text { Melle, Rice }\end{array}$ & $\begin{array}{l}\text { Gypsum Ustum, } \\
\text { Anemarrhena asphodeloides } \\
\text { Bunge, } \\
\text { Glycyrrhiza glabra L., } \\
\text { Rice }\end{array}$ & $\begin{array}{l}\text { Intravenous injection } \\
\text { of LPS ( } 200 \mathrm{ng} / \mathrm{kg})\end{array}$ & $\begin{array}{l}\text { Orally administered } \\
\text { with } \mathrm{BHD} 7 \mathrm{ml} / \mathrm{kg}\end{array}$ & $\begin{array}{l}\text { Reduce the content of IL- } \\
1 \beta \text { and TNF- } \alpha \text { in serum, } \\
\text { and TNF- } \alpha \text { in } \\
\text { hypothalamus }\end{array}$ & $\begin{array}{l}\text { New Zealand } \\
\text { rabbits } \\
\text { (weighing } \\
2.0-3.0 \mathrm{~kg} \text { ) }\end{array}$ & $\begin{array}{l}\text { Jia et al. } \\
(2013)\end{array}$ \\
\hline
\end{tabular}


TABLE 5 | Clinical trials of Chinese Patent Medicines of antipyretic.

\begin{tabular}{|c|c|c|c|c|c|c|c|}
\hline $\begin{array}{l}\text { Chinese patent } \\
\text { medicines }\end{array}$ & Disease & Subject & Study design & Intervention & Length & Outcome & References \\
\hline $\begin{array}{l}\text { Shuang-Huang- } \\
\text { Lian injection }\end{array}$ & $\begin{array}{l}\text { Acute } \\
\text { tonsillitis }\end{array}$ & $\begin{array}{l}90 \text { subjects } \\
(56 \text { men and } \\
64 \text { Women) }\end{array}$ & $\begin{array}{l}\text { Randomized } \\
\text { controlled trials }\end{array}$ & $\begin{array}{l}1 \mathrm{ml} / \mathrm{kg} \cdot \mathrm{d} \text { SHLI diluted with } \\
5 \% \text { glucose injection } 500 \mathrm{ml} \\
\text { or physiological saline } 500 \mathrm{ml} \text {, } \\
\text { intravenous drip, once a day }\end{array}$ & 5-7 days & Fever resolution & Yan et al. (2007) \\
\hline $\begin{array}{l}\text { Shuang-Huang- } \\
\text { Lian Iyophilized } \\
\text { powder for injection }\end{array}$ & $\begin{array}{l}\text { Acute upper } \\
\text { respiratory } \\
\text { tract } \\
\text { infection }\end{array}$ & $\begin{array}{l}98 \text { subjects } \\
(43 \text { men and } \\
55 \text { Women) }\end{array}$ & $\begin{array}{l}\text { Randomized } \\
\text { controlled trials }\end{array}$ & $\begin{array}{l}3 \mathrm{~g} \text { Shuang-Huang-Lian } \\
\text { lyophilized powder diluted } \\
\text { with physiological saline } \\
500 \mathrm{ml} \text {, intravenous drip, once } \\
\text { a day }\end{array}$ & 4-7 days & Fever resolution & $\begin{array}{l}\text { Ouyang et al. } \\
(2008)\end{array}$ \\
\hline $\begin{array}{l}\text { Shuang-Huang- } \\
\text { Lian oral liquid }\end{array}$ & $\begin{array}{l}\text { Acute } \\
\text { tonsillitis }\end{array}$ & $\begin{array}{l}72 \text { children } \\
\text { ( } 36 \text { male and } \\
36 \text { Female) }\end{array}$ & $\begin{array}{l}\text { Randomized } \\
\text { controlled trials }\end{array}$ & $\begin{array}{l}\text { One for children aged } 1-3 \text {, } \\
\text { three times a day; two for } \\
\text { children aged } 4-7, \text { three times } \\
\text { a day }\end{array}$ & 7 days & $\begin{array}{l}\text { Fever resolution } \\
\text { Reduce IL- } 6 \text { and TNF- } \alpha \text { in } \\
\text { serum }\end{array}$ & Ye (2019) \\
\hline $\begin{array}{l}\text { Shuang-Huang- } \\
\text { Lian injection (SHLI) }\end{array}$ & $\begin{array}{l}\text { Acute } \\
\text { tonsillitis }\end{array}$ & $\begin{array}{l}120 \text { subjects } \\
(61 \text { men and } \\
59 \text { Women) }\end{array}$ & $\begin{array}{l}\text { Randomized } \\
\text { controlled trials }\end{array}$ & $\begin{array}{l}20 \mathrm{ml} \text { SHLI was diluted in } \\
20 \mathrm{ml} \text { physiological saline for } \\
\text { ultrasonic atomization } \\
\text { inhalation treatment, twice } \\
\text { a day }\end{array}$ & 14 days & $\begin{array}{l}\text { Fever resolution; Reduce } \\
\text { IL-6 and TNF- } \alpha \text { in serum }\end{array}$ & Fu et al. (2019) \\
\hline $\begin{array}{l}\text { Shuang-Huang- } \\
\text { Lian Iyophilized } \\
\text { powder for injection }\end{array}$ & $\begin{array}{l}\text { Acute } \\
\text { tonsillitis }\end{array}$ & $\begin{array}{l}46 \text { subjects } \\
(20 \text { men and } \\
26 \text { Women) }\end{array}$ & $\begin{array}{l}\text { Randomized } \\
\text { controlled trials }\end{array}$ & $\begin{array}{l}3 \mathrm{~g} \text { Shuang-Huang-Lian } \\
\text { lyophilized powder diluted } \\
\text { with physiological saline } \\
500 \mathrm{ml} \text {, intravenous drip, once } \\
\text { a day }\end{array}$ & 5-7 days & Fever resolution & $\begin{array}{l}\text { Jiang and } \\
\text { Wang (2019) }\end{array}$ \\
\hline $\begin{array}{l}\text { Shuang-Huang- } \\
\text { Lian oral liquid }\end{array}$ & $\begin{array}{l}\text { Bacterial } \\
\text { respiratory } \\
\text { infection }\end{array}$ & $\begin{array}{l}46 \text { subjects of } \\
\text { both sexes }\end{array}$ & $\begin{array}{l}\text { Randomized } \\
\text { controlled trials }\end{array}$ & $\begin{array}{l}20 \mathrm{ml} \text { Shuang-Huang-Lian } \\
\text { oral liquid, three times a day }\end{array}$ & $3-5$ days & Fever resolution & Yang (2018) \\
\hline $\begin{array}{l}\text { Qingkailing injection } \\
\text { (QKLI) }\end{array}$ & $\begin{array}{l}\text { Acute upper } \\
\text { respiratory } \\
\text { tract } \\
\text { infection }\end{array}$ & $\begin{array}{l}46 \text { subjects } \\
(24 \text { men and } \\
21 \text { Women) }\end{array}$ & $\begin{array}{l}\text { Randomized } \\
\text { controlled trials }\end{array}$ & $\begin{array}{l}20 \mathrm{ml} \text { QKLI diluted with } 5 \% \\
\text { physiological saline } 250 \mathrm{ml} \text {, } \\
\text { intravenous drip, once a day }\end{array}$ & 7 days & Fever resolution & $\begin{array}{l}\text { Fan and Liu } \\
\text { (2011) }\end{array}$ \\
\hline Qingkailing injection & $\begin{array}{l}\text { Acute upper } \\
\text { respiratory } \\
\text { tract } \\
\text { infection }\end{array}$ & $\begin{array}{l}\text { 80subjects } \\
\text { (43 men and } \\
37 \text { Women) }\end{array}$ & $\begin{array}{l}\text { Randomized } \\
\text { controlled trials }\end{array}$ & $\begin{array}{l}20 \mathrm{ml} \text { QKLI diluted with } 5 \% \\
\text { physiological saline } 250 \mathrm{ml} \text {, } \\
\text { intravenous drip, once a day }\end{array}$ & 7 days & Fever resolution & Zhang (2019) \\
\hline Qingkailing injection & $\begin{array}{l}\text { Febrile } \\
\text { convulsion in } \\
\text { children }\end{array}$ & $\begin{array}{l}50 \text { subjects of } \\
\text { both sexes }\end{array}$ & $\begin{array}{l}\text { Randomized } \\
\text { controlled trials }\end{array}$ & $\begin{array}{l}15 \mathrm{ml} \text { for } 3 \text {-4-year-old children } \\
\text { and } 30 \mathrm{ml} \text { for } 5 \text {-6-year-old } \\
\text { children, it was added into } \\
10 \% \text { glucose injection for } \\
\text { intravenous drip once a day }\end{array}$ & 4 days & $\begin{array}{l}\text { Fever resolution; Reduce } \\
\mathrm{IL}-\beta \text {, cAMP and TNF- } \alpha\end{array}$ & $\begin{array}{l}\text { Yan and Fan } \\
\text { (2019) }\end{array}$ \\
\hline Qingkailing injection & $\begin{array}{l}\text { Acute upper } \\
\text { respiratory } \\
\text { tract } \\
\text { infection with } \\
\text { high fever }\end{array}$ & $\begin{array}{l}54 \text { subjects of } \\
\text { both sexes }\end{array}$ & $\begin{array}{l}\text { Randomized } \\
\text { controlled trials }\end{array}$ & $\begin{array}{l}\text { 16-40 ml QKLI diluted with } \\
5 \% \text { glucose injection } 250 \mathrm{ml} \\
\text { or physiological saline } 250 \mathrm{ml} \text {, } \\
\text { intravenous drip once a day }\end{array}$ & 3-7 days & Fever resolution & $\begin{array}{l}\text { Xian et al. } \\
(2010)\end{array}$ \\
\hline $\begin{array}{l}\text { Reduninglnjection } \\
\text { (RDNI) }\end{array}$ & $\begin{array}{l}\text { Fever, rash, } \\
\text { and ulcers in } \\
\text { children }\end{array}$ & $\begin{array}{l}120 \text { subjects } \\
\text { of both sexes }\end{array}$ & $\begin{array}{l}\text { Randomized, } \\
\text { double-blind, } \\
\text { parallel } \\
\text { controlled, and } \\
\text { multicenter } \\
\text { clinical trial }\end{array}$ & $\begin{array}{l}\text { Patients } 1-5 \text { years old,RDNI } \\
\text { was given at } 0.5 \mathrm{ml} / \mathrm{kg} \text { per day } \\
\text { with a maximal dosage of } \\
10 \mathrm{ml} \text {; patients } 6-10 \text { years } \\
\text { old, } 10 \mathrm{ml} \text { RDNI was given; } \\
\text { patients } 11-13 \text { years old, } \\
15 \mathrm{ml} \text { RDNI was given once } \\
\text { a day }\end{array}$ & 3-7 days & $\begin{array}{l}\text { Reduction in onset time of } \\
\text { antifebrileEffect, an } \\
\text { acceleration of body } \\
\text { temperatureRecovery, and } \\
\text { a stability of body } \\
\text { temperature after fever } \\
\text { reduction }\end{array}$ & $\begin{array}{l}\text { Zhang et al. } \\
\text { (2013a) }\end{array}$ \\
\hline $\begin{array}{l}\text { Reduninglnjection } \\
\text { (RDNI) }\end{array}$ & $\begin{array}{l}\text { Acute upper } \\
\text { respiratory } \\
\text { tract } \\
\text { infection with } \\
\text { fever }\end{array}$ & $\begin{array}{l}123 \text { subjects } \\
\text { of both sexes }\end{array}$ & $\begin{array}{l}\text { Randomized } \\
\text { controlled trials }\end{array}$ & $\begin{array}{l}0.6 \mathrm{ml} / \mathrm{kg} \text { RDNI diluted with } \\
\text { physiologicalSaline } 100 \mathrm{ml} \text {, } \\
\text { intravenous drip once a day }\end{array}$ & 3 days & Fever resolution & Li (2013) \\
\hline
\end{tabular}


TABLE 5 | (Continued) Clinical trials of Chinese Patent Medicines of antipyretic.

\begin{tabular}{|c|c|c|c|c|c|c|c|}
\hline $\begin{array}{l}\text { Chinese patent } \\
\text { medicines }\end{array}$ & Disease & Subject & Study design & Intervention & Length & Outcome & References \\
\hline Yin Qiao San (YQS) & $\begin{array}{l}\text { Acute upper } \\
\text { respiratory } \\
\text { tract } \\
\text { infection with } \\
\text { fever }\end{array}$ & $\begin{array}{l}327 \text { subjects } \\
\text { of both sexes }\end{array}$ & $\begin{array}{l}\text { Randomized, } \\
\text { double blind } \\
\text { placebo- } \\
\text { controlled trial }\end{array}$ & Two $7 \mathrm{~g}$ sachets, twice a day & 10 days & Fever resolution & $\begin{array}{l}\text { Wong et al. } \\
(2012)\end{array}$ \\
\hline Yin Qiao San & $\begin{array}{l}\text { Viral } \\
\text { influenza }\end{array}$ & $\begin{array}{l}124 \text { subjects } \\
\text { of both sexes }\end{array}$ & $\begin{array}{l}\text { Randomized, } \\
\text { single blind } \\
\text { clinical trial }\end{array}$ & $\begin{array}{l}\text { The herbs decoct until about } \\
300 \mathrm{ml} \text {. A daily dose, with } \\
\text { warm water, twice a day }\end{array}$ & 5 days & Fever resolution & $\begin{array}{l}\text { Huang et al. } \\
(2013)\end{array}$ \\
\hline
\end{tabular}

the expression of COX-2 in the hypothalamus and the production of PGE2 in the central thermoregulation of rats were inhibited (Yang et al., 2009). It has also been shown that the antipyretic action of CX may reduce the content of cAMP in the hypothalamus of the rats with fever-induced by yeast, to make the temperature set-point decrease and reach an antipyretic effect (Yang et al., 2008). It was found that in rabbits with fever caused by ET, CX not only played an antipyretic role but also change the proportion of hypothalamus 5-HT and NE (Li et al., 2003). It is suggested that the change of monoamine neurotransmitter content in the center is one of the antipyretic mechanisms of CX essential oil. Two phthalide lactones, Z-ligustilide and senkyunolide A, were identified from CX essential oil and characterized as inhibitors of TNF- $\alpha$ production in monocytes by LPS. They can also exhibit significant suppressive effects on TNF- $\alpha$-mediated NF- $\kappa B$ activation (Ran et al., 2011). In conclusion, the antipyretic effect of $\mathrm{CX}$ is related to the inhibition of the expression of COX-2, PGE2, the reduction of cAMP in the hypothalamus, the regulation of the neurotransmitter, and suppressive effects on TNF- $\alpha$-mediated NF- $\kappa \mathrm{B}$ activation.

\section{Cinnamomi Ramulus}

Cinnamomi Ramulus (CR), also called Guizhi in Chinese, is the dried twigs of Cinnamomum cassia (L.) Presl. It consists of phenylpropanoids, terpenoids, aliphatics, and its glycosides, sterols, flavonoids, and organic acids. Phenylpropanoids such as cinnamaldehyde have been considered the characteristic constituents of CR (Liu et al., 2019a). Cinnamaldehyde has been proved to have an antipyretic effect. An in vitro study showed that the expression of transient receptor potential vanilloid 1 (TRPV1) mRNA in the primary dorsal respiratory group (DRG) neurons was significantly upregulated at both $37^{\circ} \mathrm{C}$ and $39^{\circ} \mathrm{C}$ after incubation with different concentrations of cinnamaldehyde. The findings might explain the part of the mechanisms of the antipyretic action of cinnamaldehyde, which is achieved through a non-TRPA1 channel pathway (Sui et al., 2010). Rat cerebral microvascular endothelial cells (RCMEC) were cultured in M199 medium containing IL-1 $\beta$ in the presence or absence of cinnamaldehyde. The results showed that cinnamaldehyde inhibited IL- $1 \beta$-induced PGE2 production through the inhibition of COX-2 activity in cultured RCMEC (Guo et al., 2006). It provides some pharmacological evidence for clinical use of CR in fever. By using a yeast-induced fever model and IL-1 $\beta$ stimulated rat brain microvascular endothelial cells (bEnd.3) as an experimental system to determine the content of PGE2 in the hypothalamus and the supernatant of bEnd.3 (Ma et al., 2008). The results showed that cinnamaldehyde could effectively inhibit the fever response induced by yeast in rats, significantly reduce the content of PGE2 in the hypothalamus of rats with fever, and also inhibit the release of PGE2 stimulated by IL-1. The above studies show that CR can not only relieve fever through the non-TRPA1 channel but also reduce the activity of COX-2 in brain endothelial cells and the content of PGE2 in the hypothalamus of febrile rats.

\section{Forsythiae Fructus}

Forsythiae Fructus (FF), also called Lianqiao in Chinese, is the fruit of Forsythia suspensa (Thunb.) Vahl. Currently, compounds have been found in FF, including lignans, phenylethanoid glycosides, flavonoids, terpenoids, cyclohexylethanol derivatives, alkaloids, steroidals, and other compounds (Wang et al., 2018b). According to the clinical practice in TCM, FF has a significant antipyretic effect. Essential oil and forsythoside a (FTA) have been demonstrated to have an antipyretic effect (Dang et al., 2017). Subcutaneous injection of yeast caused fever in rats. The body temperature and the content of cAMP and PGE2 in the hypothalamus of the rats were observed after $2 \mathrm{~h}$. The results showed that both the essential oil and the extract of FF significantly reduced the body temperature of rats with fever. The extract of FF can downregulate cAMP and PGE2 in the hypothalamus. The FF essential oil has an antipyretic effect by downregulating cAMP in the hypothalamus (Dang et al., 2017). Previous studies have suggested that FTA can reduce the temperature of the yeastinduced fever mice. FTA significantly downregulated the expression of TRPV1 in hypothalamus and DRG of the yeast-induced fever mice, inhibited MAPKs activation of the hypothalamus and DRG, and then decreased secretion ofPGE2 (Liu et al., 2017a). Recent studies have shown that forsythoside can significantly reduce TNF-a secretion in LPS-stimulated RAW 264.7 cells, suggesting that it can reduce TNF- $\alpha$ secretion to relieve fever (Guan et al., 2013). FTA can also suppress LPS-mediated induction of the TLR4 pathway. LPS combined with TLR4 activated NF- $\mathrm{kB}$ through the primary response gene-88 (MyD88)-independent pathways. Therefore, FTA may inhibit TNF- $\alpha$ and NF- $\kappa$ B by blocking LPS/TLR4 signaling pathway (Zeng et al., 2017). Generally, FF may play an 
antipyretic role by reducing cAMP, PGE2, and TNF- $\alpha$ in the hypothalamus, suppressing TRPV1 expression, and the LPS/ TLR4 signaling pathway.

\section{Lonicera Japonica Flos}

Lonicera Japonica Flos (LJ), also known as Jin Yin Hua, is the dry flower buds of Lonicera japonica Thunb. It is abundant with iridoids, essential oil, flavones, organic acids, and triterpenoid saponins (Shang et al., 2011). The aqueous extract from LJ has been used in TCM for treating fever for thousands of years (Xu et al., 2007). In rabbits with fever caused by IL-1 $\beta$, based on observing the antipyretic effect of LJ, the expression of prostaglandin receptor EP3 in the preoptic-anterior hypothalamus (POAH) of New Zealand rabbits was detected. The results showed that $\mathrm{LJ}$ has an antipyretic effect, and its mechanism may be related to the inhibition of EP3 expression in POAH (Xie et al., 2009). The current study investigated the effect of LJ water extracts on inhibition of both COX-1 and COX-2 activity. The result showed that the inhibitory effect of LJ water extract on COX-2 activity after boiling was four times. The COX2 transcriptional inhibition of boiled LJ extracts may be due to the action of bifidoflavonoids or similar compounds through NF- $\kappa B$ (Xu et al., 2007). The antipyretic effect of LJ may inhibit the synthesis of PGE2 by inhibiting the activity of COX-2, as well as inhibiting EP3 expression in POAH. Chlorogenic acid (CGA) is the main active component of LJ, however, CGA did not inhibit LPS induced fever even at the highest test dose (200 mg/kg) (Dos Santos et al., 2006). Therefore, CGA may lack antipyretic activity; the material basis of the antipyretic effect of LJ needs further study.

\section{Other Single Chinese Herbal Medicines of Antipyretics}

The above are six commonly used TCM in clinical practice. Their active components play an antipyretic role through different mechanisms. The chemical structure formula is shown in Figure 4. In addition to the above six commonly used TCM (Table 2), Ephedrae Herba, Gypsum Fibrosum, Gardeniae Fructus, Bubali Cornu, Houttuyniae Herba, Andrographis Herba, and Puerariae Lobatae Radix also have significant antipyretic effects (Table 3 ).

\section{CHINESE PATENT MEDICINES AND COMPLEX PRESCRIPTIONS IN THE TREATMENT OF FEVER \\ Qingkailing Injection}

Qingkailing injection (QKLI) is a composite formula of TCM with a significant antipyretic action (Gao et al., 2013a). It comprises eight TCMs or extracts thereof, including Isatidis Radix, Lonicera Japonica Flos, Gardeniae Fructus, Bubali Cornu, Margaritifera Concha, Baicalinum, Acidum Cholicum, and Acidum Hyodesoxy-cholicum (Yan et al., 2005). Plasma pharmacokinetics study of QKLI demonstrated that baicalin 2) and geniposide 9) might be the potential active antipyretic components of QKLI (Zhang et al., 2016). Baicalin and geniposide could be detected in the hypothalamic dialysate after IV administration of QKLI. However, metabolomics biomarkers of QKLI were highly correlated with baicalin while gardenoside has no statistically significant correlation with these biomarkers (Zhang et al., 2017). Therefore, baicalin may be the more important active component for QKLI to play the role of antipyretic. The network pharmacology study of the antipyretic effect of baicalin shows that baicalin can regulate fever-related molecules NO by targeting on caspase 3 (CASP3) and regulate cAMP, PGE2 to produce antipyretic effect (Zhang et al., 2017). The mechanism of antipyretic action of SR includes baicalin; it plays an antipyretic role by inhibiting the release of IL-6, IL- $1 \beta$, TNF- $\alpha$, and PGE2, the activation of NF- $\kappa B$, and the excessive production of hydroxyl radicals. From QKLI, baicalin was the only antipyretic component screened; it alone cannot represent the antipyretic activity of QKLI. Other antipyretic components in QKLI that play their antipyretic role through humoral pathway. In the study of urine metabolomics, it was found that QKLI can reduce the content of tryptophan by $5-\mathrm{HT}$ and repair the disorder of amino acid metabolism on yeast induced fever rats (Gao et al., 2013a). A plasma study shows that QKLI can correct the interference of amino acid metabolism and lipid metabolism to relieve fever (Qin et al., 2016). However, except baicalin, other antipyretic components of QKLI are seldom studied, and its antipyretic components need to be further studied.

\section{Shuang-Huang-Lian Preparation}

SHL is a famous TCM recipe, which was included in Chinese pharmacopoeia in 2015. It contains LJ, SR, and FF; it is clinically used to treat fever and infectious diseases such as acute upper respiratory tract infection (Gao et al., 2014a). SHL products are administered in a variety of different routes (e.g., oral, injectable, and pulmonary routes) (Gao et al., 2014c). Three effective ingredients, chlorogenic acid (17), baicalin (2), and forsythin (7), are officially recorded as quality control standards. Baicalin has an antipyretic effect by inhibiting the release of IL- 6 , IL-1 $\beta$, TNF- $\alpha$, and PGE2, the activation of NF- $\kappa B$, and the excessive production of hydroxyl radicals (See 6.2). Forsythin may have an antipyretic effect by reducing CAMP, PGE2, and TNF- $\alpha$ in the hypothalamus, suppressing TRPV1 expression, and the LPS/ TLR4 signaling pathway (See 6.6). The study first evaluated the antipyretic effect of SHL injection (SHLI) using UPLC-QTOF/MS-based metabolomics study to reveal the antipyretic mechanism of SHLI on the yeast-induced pyrexia rat model. The result shows that SHLI might contribute to the repair of lipid metabolism, amino acid metabolism, and energy metabolism to work antipyretic effects (Gao et al., 2014b). It reported that baicalin in SHL was metabolized to baicalein in a study, baicalin was used as a representative compound to study the pharmacokinetics of SHL. It was found that the compound prescription might prolong the effect of baicalin in vivo ( $\mathrm{Di}$ et al., 2006). It suggests that the antipyretic effect of SHL may be better than that of SR. Another study was conducted to compare the antipyretic effect of LJ and SHL on rectal temperature changes induced by yeast. The results indicated 
that SHL showed a better antipyretic effect than LJ (Gao et al., 2014). In conclusion, the antipyretic effect of SHL is better than that of single herb.

\section{Others}

In addition to the QKLI and SHL series preparations, Jinxin oral liquid, Yin Qiao San, Hao Jia Xu Re Qing Granules, and Reduning injection are used in clinical antipyretic treatment. Gegen Qinlian decoction and Bai-Hu decoction are two classical antipyretic prescriptions that have also been proved to have significant antipyretic effects (Table 4).

\section{CLINICAL TRIALS}

In the study of the antipyretic mechanism of TCM, various models have been developed to simulate the natural fever of experimental animals. However, fever is an important clinical manifestation of many diseases, so most of the clinical trials of antipyretics in TCM are focused on acute upper respiratory tract infection, acute tonsillitis, acute otitis media, and other diseases (Li, 2002; Zhang et al., 2013b). At present, there are a few clinical trials on the antipyretic effect of single Chinese herbal medicines (Table 5). The clinical trials of antipyretic Chinese patent medicine mainly include SHL series preparations and QKLI. It's worth noting that the clinical trials of antipyretic TCMs are concentrated on infectious fever, but high-quality clinical trials are lacking. Clinical trials study to evaluate the effect of antipyretic TCMs will use more strict protocols, concealment of allocation, and double-blinding, in order to ensure the compliance of international acceptable standards.

\section{CONCLUSION AND PERSPECTIVES}

Since the global outbreak of the infectious disease COVID-19 in 2019, China has taken strong measures to quickly engage in the fight against the COVID-19. TCM has played an important role in the prevention and treatment of COVID-19 because of its unique insights and experiences. For patients with mild symptoms, TCM early intervention can effectively prevent the disease from turning into severe. In severe cases, TCM improves the symptoms to win the rescue time for the patients. TCM has own characteristics such as holistic concept, syndrome differentiation and treatment, strengthening the body resistance to eliminate pathogenic factors. Judging from the

\section{REFERENCES}

Beeson, P. (1948). Temperature-elevating effect of a substance obtained from polymorphonuclear leucocytes. J. Clin. Invest. 27 (4), 524-531.

Billiau, A., and Matthys, P. (2009). Interferon-gamma: a historical perspective. Cytokine Growth Factor. Rev. 20 (2), 97-113. doi:10.1016/j.cytogfr.2009.02.004

Blatteis, C. M., Li, S., Li, Z., Feleder, C., and Perlik, V. (2005). Cytokines, PGE2 and endotoxic fever: a re-assessment. Prostag. Oth. Lipid Mediat. 76 (1-4), 1-18. doi:10.1016/j.prostaglandins.2005.01.001 current treatment plan, TCM treats patients with COVID-19 based on the idea of syndrome differentiation and treatment. In order to improve the fever in some patients, prescriptions need to be compatible with antipyretic TCMs.Therefore, this paper summarized the mechanisms of fever from two aspects of pathology and physiology. On this basis, combined with the chemical composition and pharmacological action of TCM, it analyzed the mechanisms of the antipyretic effects of TCM through various ways, so as to provide reference for the efficient utilization of existing drugs.

It must be pointed out that in the face of the spread of new epidemics, due to the particularity of the disease and the urgency of formulating effective diagnosis and treatment plans, suitable treatment models have been developing based on basic theories and clinical experiences. Therefore, it is important to choose drugs with a clear therapeutic effect and clinical basis. The single Chinese medicine and compound preparations of TCM which have specific antipyretic effects listed in this paper are widely used in clinical practice, and can effectively improve the symptoms of fever in acute respiratory infections and control infections. TCM has the unique properties of multi-components and multi-targets. The majority of these mentioned drugs may not only exert the effects of antipyretic, but also have the properties of antiinflammation, and immunity enhancement; and some of them are antiviral, and may be promising medicines for the treatment or adjuvant treatment of COVID-19 patients.

\section{AUTHOR CONTRIBUTIONS}

D-KZ and R-CX put forward the idea; L-LM wrote the manuscript and made the figures; H-ML, C-HL, Y-NH, FW, and $\mathrm{H}-\mathrm{ZH}$ collected the literature; $\mathrm{LH}$ and MY contributed to the revisions.

\section{FUNDING}

We are grateful to the support of National Natural Science Foundation Project (81773918), Open Project of State key Laboratory of Innovation Medicine and High Efficiency and Energy Saving Pharmaceutical Equipment in Jiangxi University of Traditional Chinese Medicine (GZSYS202003), and Outstanding Young Science and Technology Talents Project of the Science and Technology Department of Sichuan Province (2019JDJQ0007).

Blatteis, C. M., Sehic, E., and Li, S. (1998). Afferent pathways of pyrogen signaling Ann. N. Y Acad. Sci. 856 (1), 95-107. doi:10.1111/j.1749-6632.1998.tb08318.x Blatteis, C. M., Sehic, E., and Li, S. (2000). Pyrogen sensing and signaling: old views and new concepts. Clin. Infect. Dis. 31 (5), S168-S177. doi:10.1086/317522

Blatteis, C. M. (2006). Endotoxic fever: new concepts of its regulation suggest new approaches to its management. Pharmacol. Ther. 111 (1), 194-223. doi:10.1016/ j.pharmthera.2005.10.013

Blatteis, C. M., Li, S., Li, Z., Perlik, V., and Feleder, C. (2004). Complement is required for the induction of endotoxic fever in Guinea pigs and mice. J. Therm. Biol. 29, 369-381. doi:10.1016/j.jtherbio.2004.08.009 
Blomqvist, A., and Engblom, D. (2013). Mechanisms of fever in humans. Int. J. Microbiol. Immunol. Res. 2 (5), 37-43.

Bruno, M., Piozzi, F., and Rosselli, S. (2002). Natural and hemisynthetic neoclerodane diterpenoids from Scutellaria and their antifeedant activity. Nat. Prod. Rep. 19 (3), 357-378. doi:10.1039/b111150g

Callery, M., Mangino, M., and Flye, M. (1991). A biologic basis for limited Kupffer cell reactivity to portal-derived endotoxin. Surgery 110 (2), 221-230.

Capuano, A., Scavone, C., Racagni, G., and Scaglione, F. (2020). NSAIDs in patients with viral infections, including Covid-19: victims or perpetrators? Pharmacol. Res. 157, 104849. doi:10.1016/j.phrs.2020.104849

Chen, E., Chen, J., Cao, S. L., Zhang, Q. Z., and Jiang, X. G. (2010). Preparation of nasal temperature-sensitive in situ gel of Radix Bupleuri and evaluation of the febrile response mechanism. Drug Dev. Ind. Pharm. 36 (4), 490-496. doi:10. 3109/03639040903264371

Chen, J., Qi, T., Liu, L., Ling, Y., Qian, Z., Li, T., et al. (2020). Clinical progression of patients with COVID-19 in Shanghai, China. J. Infect. 80 (5), e1-e6. doi:10. 1016/j.jinf.2020.03.004

Chen, Z., Zhang, C., Gao, F., Fu, Q., Fu, C., He, Y., et al. (2018). A systematic review on the rhizome of Ligusticum chuanxiong Hort. (Chuanxiong). Food Chem. Toxicol. 119 (18), 309-325. doi:10.1016/j.fct.2018.02.050

Ching, S., Zhang, H., Belevych, N., He, L., Lai, W., Pu, X. A., et al. (2007). Endothelial-specific knockdown of interleukin-1 (IL-1) type 1 receptor differentially alters CNS responses to IL-1 depending on its route of administration. J. Neurosci. 27 (39), 10476-10486. doi:10.1523/jneurosci. 3357-07.2007

Conti, B., Tabarean, I., Andrei, C., and Bartfai, T. (2004). Cytokines and fever. Front. Biosci. 9 (12), 1433-1449. doi:10.2741/1341

Dang, J., Yuan, A., Luo, L., Quan, Y., Zhao, M. J., and Li, Y. X. (2017). Antipyretic effect of Forsythia suspense extract and Forsythia oil on yeast-induced fever rats and its mechanism. Nat. Prod. Res. Dev. 29 (9), 1542-1545. doi:10.16333/j.10016880.2017.9.015

de Girolamo, L., Peretti, G. M., Maffulli, N., and Brini, A. T.(2020).Covid-19-The real role of NSAIDs in Italy. J. Orthop. Surg. Res. 15 (1), 165. doi:10.1186/ s13018-020-01682-x

Dewitt, S., Chavez, S. A., Perkins, J., Long, B., and Koyfman, A. (2017). Evaluation of fever in the emergency department. Am. J. Emerg. Med. 35 (11), 1755-1758. doi:10.1016/j.ajem.2017.08.030

Di, B., Feng, N., and Liu, W. (2006). Pharmacokinetic comparisons of ShuangHuang-Lian with the different combinations of its constitutional herbs. J. Ethnopharmacol. 107 (3), 401-405. doi:10.1016/j.jep.2006.03.030

Dinarello, C. A. (1996). Biologic basis for interleukin-1 in disease. Blood. 87 (6), 2095-2147. doi:10.1182/blood.v87.6.2095.bloodjournal8762095

Dinarello, C. A. (1999). Cytokines as endogenous pyrogens. J. Infect. Dis. 179, S294-S304. doi:10.1086/513856

Dinarello, C. A. (2004). Infection, fever, and exogenous and endogenous pyrogens: some concepts have changed. J. Endotoxin Res. 10 (4), 201-222. doi:10.1179/ 096805104225006129

Dos Santos, M. D., Almeida, M. C., Lopes, N. P., De Souza, G. E., and Bulletin, P. (2006). Evaluation of the anti-inflammatory, analgesic and antipyretic activities of the natural polyphenol chlorogenic acid. Biol. Pharm. Bull. 29 (11), 2236-2240. doi:10.1248/bpb.29.2236

Equils, O., Kellogg, C., McGregor, J., Gravett, M., Neal-Perry, G., and Gabay, C. (2020). The role of the IL-1 system in pregnancy and the use of IL-1 system markers to identify women at risk for pregnancy complications $\dagger$ Biol. Reprod. 103, 684-694. doi:10.1093/biolre/ioaa102

Eskilsson, A., Mirrasekhian, E., Dufour, S., Schwaninger, M., Engblom, D., and Blomqvist, A. (2014). Immune-induced fever is mediated by IL-6 receptors on brain endothelial cells coupled to STAT3-dependent induction of brain endothelial prostaglandin synthesis. J. Neurosci. 34 (48), 15957-15961. doi:10.1523/JNEUROSCI.3520-14.2014

Evans, S. S., Repasky, E. A., and Fisher, D. T. (2015). Fever and the thermal regulation of immunity: the immune system feels the heat. Nat. Rev. Immunol. 15 (6), 335-349. doi:10.1038/nri3843

Fan, X., and Liu, J. (2011). Efficacy observation of Qingkailing injection in the treatment of acute upper respiratory tract infection. China Pharm. 22 (8), 701-702. doi:10.1002/crat.201000663
Fang, L., Karakiulakis, G., and Roth, M. (2020). Are patients with hypertension and diabetes mellitus at increased risk for COVID-19 infection? Lancet Respir. Med. 8 (4), e21. doi:10.1016/S2213-2600(20)30116-8

Fu, H., Xiong, X., and Wang, Q. (2019). Effect of atomization inhalation of shuanghuanglian injection in treatment of chronic tonsillitis and its influence on levels of IL-6, hs-CRP and TNF- $\alpha$;. Chin. Arch. Traditional Chin. Med. 30 (2), 392-395. doi:10.13193/j.issn.1673-7717.2019.02.033

Gao, Y., Fang, L., Cai, R., Zong, C., Chen, X., Lu, J., et al. (2014a). Shuang-HuangLian exerts anti-inflammatory and anti-oxidative activities in lipopolysaccharide-stimulated murine alveolar macrophages. Phytomedicine 21 (4), 461-469. doi:10.1016/j.phymed.2013.09.022

Gao, X., Guo, M., Li, Q., Peng, L., Liu, H., Zhang, L., et al. (2014b). Plasma metabolomic profiling to reveal antipyretic mechanism of Shuang-huang-lian injection on yeast-induced pyrexia rats. PLoS One 9 (6), e100017. doi:10.1371/ journal.pone. 0100017

Gao, X., Guo, M., Peng, L., Zhao, B., Su, J., Liu, H., et al. (2013a). UPLC Q-TOF/MSBased metabolic profiling of urine reveals the novel antipyretic mechanisms of qingkailing injection in a rat model of yeast-induced pyrexia. Evid. Based Complement. Alternat Med. 2013, 864747. doi:10.1155/2013/864747

Gao, X., Guo, M., Zhao, B., Peng, L., Su, J., Bai, X., et al. (2013b). A urinary metabonomics study on biochemical changes in yeast-induced pyrexia rats: a new approach to elucidating the biochemical basis of the febrile response. Chem. Biol. Interact 204 (1), 39-48. doi:10.1016/j.cbi.2013.04.001

Gao, R., Lin, Y., Liang, G., Yu, B., and Gao, Y. (2014c). Comparative pharmacokinetic study of chlorogenic acid after oral administration of Lonicerae Japonicae Flos and Shuang-Huang-Lian in normal and febrile rats. Phytother Res. 28 (1), 144-147. doi:10.1002/ptr.4958

Gao, X., Huang, C., Geng, T., Chen, X., Wang, J., Liu, J., et al. (2020). Serum and urine metabolomics based on UPLC-Q-TOF/MS reveals the antipyretic mechanism of Reduning injection in a rat model. J. Ethnopharmacol 250 112429-112455. doi:10.1016/j.jep.2019.112429

Guan, J., Shen, H., Zhang, Y., and Cui, D. (2013). Effects of forsythoside on lipopolysaccharide (LPS)-stimulated RAW264. 7 macrophages. Afr. J. Pharm. Pharmaco. 7 (26), 1847-1853. doi:10.5897/ajpp2013.3584

Guan, W. J., Ni, Z. Y., Hu, Y., Liang, W. H., Ou, C. Q., He, J. X., et al. (2020). Clinical characteristics of coronavirus disease 2019 in China. N. Engl. J. Med. 382 1708-1720. doi:10.1056/NEJMoa2002032

Guo, J. Y., Huo, H. R., Zhao, B. S., Liu, H. B., Li, L. F., Ma, Y. Y., et al. (2006). Cinnamaldehyde reduces IL-1beta-induced cyclooxygenase-2 activity in rat cerebral microvascular endothelial cells. Eur. J. Pharmacol. 537 (1-3), 174-180. doi:10.1016/j.ejphar.2006.03.002

Guo, M., Gu, H., Song, Y., Peng, L., Liu, H., Zhang, L., et al. (2014). Characterization of rational biomarkers accompanying fever in yeastinduced pyrexia rats using urine metabolic footprint analysis. J. Pharm. Biomed. Anal. 95 68-75. doi:10.1016/j.jpba.2014.02.011

Haddad, J., and Land, S. (2002). Redox/ROS regulation of lipopolysaccharideinduced mitogen-activated protein kinase (MAPK) activation and MAPKmediated TNF- $\alpha$ biosynthesis. Br. J. Pharmacol. 135 (2), 520-536. doi:10. 1038/sj.bjp.0704467

Hamzic, N., Tang, Y., Eskilsson, A., Kugelberg, U., Ruud, J., Jönsson, J. I., et al. (2013). Interleukin-6 primarily produced by non-hematopoietic cells mediates the lipopolysaccharide-induced febrile response. Brain Behav. Immun. 33 123-130. doi:10.1016/j.bbi.2013.06.006

Harden, L. M., du Plessis, I., Poole, S., and Laburn, H. P. (2008). Interleukin (IL)-6 and IL-1 beta act synergistically within the brain to induce sickness behavior and fever in rats. Brain Behav. Immun. 22 (6), 838-849. doi:10.1016/j.bbi.2007. 12.006

Harré, E., Roth, J., Pehl, U., Kueth, M., Gerstberger, R., and Hübschle, T. (2002). Selected contribution: role of IL-6 in LPS-induced nuclear STAT3 translocation in sensory circumventricular organs during fever in rats. J. Appl. Physiol. 92 (6), 2657-2666. doi:10.1152/japplphysiol.00822.2001

Hou, C. C., Lin, H., Chang, C. P., Huang, W. T., and Lin, M. T. (2011). Oxidative stress and pyrogenic fever pathogenesis. Eur. J. Pharmacol. 667 (1-3), 6-12. doi:10.1016/j.ejphar.2011.05.075

Huang, B., and Chang, L. (2016). Effects of different decocting methods on antipyretic and anti-inflammatory of yinqiao powder. Liaoning J. Tradit Chin. Med. 43 (5), 141-143. doi:10.13192/j.issn.1000-1719.2016.05.047 
Huang, T., Zhou, H., Li, Y., Yang, Z., and Ou, A. (2013). Inhibitory effects of Yinqiaosan and its disassembled prescription on viral influenza. Bioinformatics Biomed. 12, 69-76. doi:10.1109/BIBM.2013.6732641

Huang, W. T., Lin, M. T., and Chang, C. P. (2006). An NMDA receptor-dependent hydroxyl radical pathway in the rabbit hypothalamus may mediate lipopolysaccharide fever. Neuropharmacology 50 (4), 504-511. doi:10.1016/j. neuropharm.2005.10.012

Huang, Z., Pan, X., Zhou, J., Leung, W. T., Li, C., and Wang, L. (2019). Chinese herbal medicine for acute upper respiratory tract infections and reproductive safety: a systematic review. Biosci. Trends 13 (2), 117-129. doi:10.5582/bst.2018. 01298

Idrisusman, M. S., Johnafrica, L., Akuodor, G. C., Ugwu, T. C., and Osunkwo, U. A. (2010). Antinociceptive and antipyretic properties of the pharmaceutical herbal preparation, Radix bupleuri in rats. J. Med. Plants Res. 4 (8), 659-663. doi:10. 1016/j.jep.2008.10.024

Jia, L., Li, R., Ma, J., Fan, Y., and Li, H. (2013). Effects of Bai-Hu decoction on fever induced by lipopolysaccharide. Kaohsiung J. Med. Sci. 29 (3), 128-132. doi:10. 1016/j.kjms.2012.08.022

Jiang, H. Q., and Wang, G. Q. (2019). Effect observation of 46 cases of acute tonsillitis (pharyngitis) treated by powder needle of shuanghuanglian. World Latest Med. Inf. 19 (10), 96-101. doi:10.19613/j.cnki.1671-3141.2019.10.064

Jin, G., Li, B., and Wang, S. (2014). Research on the mechanism, the effects and material foundation of $\mathrm{ChaiHu}$ in relieving fever. West. J. Traditional Chin. Med. 2 (2), 8-13.

Kang, S., Tanaka, T., Narazaki, M., and Kishimoto, T. (2019). Targeting interleukin-6 signaling in clinic. Immunity 50 (4), 1007-1023. doi:10.1016/j. immuni.2019.03.026

Kluger, M. J. (1991). Fever: role of pyrogens and cryogens. Physiol. Rev. 71 (1), 93-127. doi:10.1152/physrev.1991.71.1.93

Konsman, J. P., Vigues, S., Mackerlova, L., Bristow, A., and Blomqvist, A. (2004). Rat brain vascular distribution of interleukin-1 type-1 receptor immunoreactivity: relationship to patterns of inducible cyclooxygenase expression by peripheral inflammatory stimuli. J. Comp. Neurol. 472 (1), 113-129. doi:10.1002/cne.20052

Kumar, H., Kawai, T., and Akira, S. (2011). Pathogen recognition by the innate immune system. Int. Rev. Immunol. 30 (1), 16-34. doi:10.3109/08830185.2010.529976

Lenhardt, R., Negishi, C., Sessler, D. I., Vuong, K., Bastanmehr, H., Kim, J. S., et al. (1999). The effects of physical treatment on induced fever in humans. Am. J. Med. 106 (5), 550-555. doi:10.1016/s0002-9343(99)00068-6

Li, C., Lin, G., and Zuo, Z. (2011). Pharmacological effects and pharmacokinetics properties of Radix Scutellariae and its bioactive flavones. Biopharm. Drug Dispos 32 (8), 427-445. doi:10.1002/bdd.771

Li, Q., and Ge, X. (2010). [Efffect of baicalin on antipyresis and influence on cytokine]. Zhongguo Zhong Yao Za Zhi 35 (8), 1068-1072. doi:10.4268/ cjcmm20100829

Li, Q., Wang, H., Li, X., Zheng, Y., Wei, Y., Zhang, P., et al. (2020). The role played by traditional Chinese medicine in preventing and treating COVID-19 in China. Front. Med. 14 (5), 681-688. doi:10.1007/s11684-020-0801-x

Li, S., Ballou, L., Morham, S., and Blatteis, C. (2001). Cyclooxygenase-2 mediates the febrile response of mice to interleukin-1beta. Brain Res. 910 (1-2), 163-173. doi:10.1016/s0006-8993(01)02707-x

Li, S., Holers, V., Boackle, S., and Blatteis, C. (2002). Modulation of mouse endotoxic fever by complement. Infect. Immun. 70 (5), 2519-2525. doi:10. 1128/iai.70.5.2519-2525.2002

Li, W. (2002). The curative effect observation of shuanghuanglian and penicillin on acute tonsillitis. Lin Chuang Er Bi Yan Hou Ke Za Zhi 16 (9), 475-476.

Li, Y. (2013). Comparison of clinical effect of acute upper respiratory tract infection of R eduning and ribavirin therapy Chin J. Mod. Drug 7 (9), 1-3. doi:10.14164/j. cnki.cn11-5581/r.2013.09.151

Li, Z., Yang, J., Hu, R., and Song, J. (2003). The antipyretic effect and it's partial mechanism of the essential oil Ligusticum chuanxiong Hort. Inf. Traditional Chin. Med. 6 (6), 12-15.

Liu, C., Su, H., Wan, H., Qin, Q., Wu, X., Kong, X., et al. (2017a). Forsythoside A exerts antipyretic effect on yeast-induced pyrexia mice via inhibiting transient receptor potential vanilloid 1 function. Int. J. Biol. Sci. 13 (1), 65. doi:10.7150/ ijbs. 18045

Liu, T., Li, S., Tian, X., Li, Z., Cui, Y., Han, F., et al. (2017b). A plasma metabonomic analysis on potential biomarker in pyrexia induced by three methods using ultra high performance liquid chromatography coupled with Fourier transform ion cyclotron resonance mass spectrometry. J. Chromatogr. B Analyt Technol. Biomed. Life Sci. 1063, 214-225. doi:10. 1016/j.jchromb.2017.08.028

Liu, J., Zhang, Q., Li, R. L., Wei, S. J., Huang, C. Y., Gao, Y. X., et al. (2019a). The traditional uses, phytochemistry, pharmacology and toxicology of Cinnamomi ramulus: a review. J. Pharm. Pharmacol. 72 (3), 319-342. doi:10.1111/jphp.13189

Liu, T., Li, R., Cui, Y., Yu, Z., and Zhao, Y. (2019b). Metabonomic analysis of potential plasma biomarkers in pyrexia rats after treatment with Gegenqinlian decoction, aspirin and itraconazole by UHPLC-FT-ICR-MS. J. Med. Plants Res. 11, 1-27. doi:10.1016/j.jpha.2019.11.007

Liu, R., Huang, Q., Shan, J., Duan, J. A., Zhu, Z., Liu, P., et al. (2016). Metabolomics of the antipyretic effects of Bubali Cornu (water buffalo horn) in rats. PLoS One. 11 (7), e0158478. doi:10.1371/journal.pone.0158478

Luo, H., Ma, L. L., Liu, H. M., Liao, W., Xu, R. C., Ci, Z. M., et al. (2020a).Research progress on main symptoms of novel coronavirus pneumonia improved by traditional Chinese medicine. Front. Pharmacol. 11, 556885. doi:10.3389/fphar. 2020.556885

Luo, H., Yang, M., Tang, Q. L., Hu, X. Y., Willcox, M. L., and Liu, J. P. (2020b). Characteristics of registered clinical trials on traditional Chinese medicine for coronavirus disease 2019 (COVID-19): a scoping review. Eur. J. Integr. Med. 12, 101251. doi:10.1016/j.eujim.2020.101251

Ma, Y. Y., Huo, H. R., Li, C. H., Zhao, B. S., Li, L. F., Sui, F., et al. (2008). Effects of cinnamaldehyde on PGE2 release and TRPV4 expression in mouse cerebral microvascular endothelial cells induced by interleukin-1beta. Biol. Pharm. Bull. 31 (3), 426-430. doi:10.1248/bpb.31.426

Michie, H. R., Spriggs, D., Manogue, K., Sherman, M., Revhaug, A., o’Dwyer, S., et al. (1988). Tumor necrosis factor and endotoxin induce similar metabolic responses in human beings. Surgery 104 (2), 280-286.

Miller, A. J., Hopkins, S. J., and Luheshi, G. N. (1997). Sites of action of IL-1 in the development of fever and cytokine responses to tissue inflammation in the rat. Br. J. Pharmacol. 120 (7), 1274-1279. doi:10.1038/sj.bjp.0701049

Morimoto, A., Murakami, N., Nakamori, T., and Watanabe, T. (1987). Evidence for separate mechanisms of induction of biphasic fever inside and outside the blood-brain barrier in rabbits. J. Physiol. 383 (1), 629-637. doi:10.1113/jphysiol. 1987.sp016433

Myers, R., Simpson, C., Higgins, D., Nattermann, R., Rice, J., Redgrave, P., et al. (1976). Hypothalamic $\mathrm{Na}+$ and $\mathrm{Ca}++$ ions and temperature set-point: new mechanisms of action of a central or peripheral thermal challenge and intrahypothalamic 5-HT, NE, PGEi and pyrogen. Brain Res. Bull. 1 (3), 301-327. doi:10.1016/0361-9230(76)90102-7

Prajitha, N, Athira, S. s., and Mohanan, P. v. (2019). Comprehensive biology of antipyretic pathways. Cytokine 116 120-127. doi:10.1016/j.cyto.2019.01.008

Nadeau, S., and Rivest, S. (1999). Regulation of the gene encoding tumor necrosis factor alpha (TNF-alpha) in the rat brain and pituitary in response in different models of systemic immune challenge. J. Neuropathol. Exp. Neurol. 58 (1), 61-77. doi:10.1097/00005072-199901000-00008

Nadjar, A., Tridon, V., May, M. J., Ghosh, S., Dantzer, R., Amédée, T., et al. (2005). NFkappaB activates in vivo the synthesis of inducible Cox-2 in the brain. J. Cereb. Blood Flow Metab. 25 (8), 1047-1059. doi:10.1038/sj.jcbfm.9600106

Nakahata, N., Kutsuwa, M., Kyo, R., Kubo, M., Hayashi, K., and Ohizumi, Y. (1998). Analysis of inhibitory effects of scutellariae radix and baicalein on prostaglandin E2 production in rat C6 glioma cells. Am. J. Chin. Med. 26, 311-323. doi:10.1142/S0192415X9800035X

Nilsberth, C., Elander, L., Hamzic, N., Norell, M., Lönn, J., Engström, L., et al. (2009). The role of interleukin-6 in lipopolysaccharide-induced fever by mechanisms independent of prostaglandin E2. Endocrinology 150 (4), 1850-1860. doi:10.1210/en.2008-0806

Niven, D. J., Laupland, K. B., Tabah, A., Vesin, A., Rello, J., Koulenti, D., et al. (2013). Diagnosis and management of temperature abnormality in ICUs: a EUROBACT investigators' survey. Crit. Care 17 (6), R289. doi:10.1186/cc13153 Ogoina, D. (2011). Fever, fever patterns and diseases called 'fever'--a review. J. Infect. Public Health 4 (3), 108-124. doi:10.1016/j.jiph.2011.05.002

Oh, G., Pae, H., Choi, B., Seo, E., Kim, D., Shin, M., et al. (2004). 20(S)Protopanaxatriol, one of ginsenoside metabolites, inhibits inducible nitric oxide synthase and cyclooxygenase-2 expressions through inactivation of nuclear factor-kappaB in RAW 264.7 macrophages stimulated with lipopolysaccharide. Cancer Lett. 205 (1), 23-29. doi:10.1016/j.canlet.2003.09.037 
Oka, T. (2004). Prostaglandin E2 as a mediator of fever: the role of prostaglandin E (EP) receptors. Front. Biosci. 9 (3), 3046-3057. doi:10.2741/1458

Ouyang, J., Li, W., and Tang, R. (2008). Clinical analysis of 98 cases of upper respiratory tract infection treated by shuanghuanglian lyophilized powder for injection. china Med. herald 5 (31), 74-75.

Pakai, E., Tekus, V., Zsiboras, C., Rumbus, Z., Olah, E., Keringer, P., et al. (2018). The neurokinin-1 receptor contributes to the early phase of lipopolysaccharideinduced fever via stimulation of peripheral cyclooxygenase-2 protein expression in mice. Front. Immunol. 9, 166. doi:10.3389/fimmu.2018.00166

Pecchi, E., Dallaporta, M., Jean, A., Thirion, S., and Troadec, J. (2009). Prostaglandins and sickness behavior: old story, new insights. Physiol. Behav. 97 (3-4), 279-292. doi:10.1016/j.physbeh.2009.02.040

Peindaries, R., and Jacob, J. (1971). Interactions between 5-hydroxytryptamine and a purified bacterial pyrogen when injected into the lateral cerebral ventricle of the wake rabbit. Eur. J. Pharmacol. 13 (3), 347-355. doi:10.1016/0014-2999(71) 90225-1

Perlik, V., Li, Z., Goorha, S., Ballou, L. R., and Blatteis, C. M. (2005). LPS-activated complement, not LPS per se, triggers the early release of PGE2 by Kupffer cells. Am. J. Physiol. Regul. Integr. Comp. Physiol. 289 (2), R332-R339. doi:10.1152/ ajpregu.00567.2004

Prajitha, N., Athira, S. S., and Mohanan, P. V. (2018). Pyrogens, a polypeptide produces fever by metabolic changes in hypothalamus: mechanisms and detections. Immunol. Lett. 204 38-46. doi:10.1016/j.imlet.2018.10.006

Qian, W., Shan, J., Shen, C., Yang, R., Xie, T., and Di, L. (2019). Brain metabolomics reveal the antipyretic effects of Jinxin oral liquid in Young rats by using gas chromatography-mass spectrometry. Metabolites 9 (1), 6. doi:10.3390/ metabo9010006

Qin, L., Zhang, Z., Guo, M., Zhang, Q., Wang, Q., Lu, Z., et al. (2016). Plasma metabolomics combined with lipidomics profiling reveals the potential antipyretic mechanisms of Qingkailing injection in a rat model. Chem. Biol. Interact 254, 24-33. doi:10.1016/j.cbi.2016.05.022

Ran, X., Ma, L., Peng, C., Zhang, H., and Qin, L. P. (2011). Ligusticum chuanxiong Hort: a review of chemistry and pharmacology. Pharm. Biol. 49 (11), 1180-1189. doi:10.3109/13880209.2011.576346

Ridder, D. A., Lang, M. F., Salinin, S., Röderer, J. P., Struss, M., Maser-Gluth, C., et al. (2011). TAK1 in brain endothelial cells mediates fever and lethargy. J. Exp. Med. 208 (13), 2615-2623. doi:10.1084/jem.20110398

Rincon, M. (2012). Interleukin-6: from an inflammatory marker to a target for inflammatory diseases. Trends Immunol. 33 (11), 571-577. doi:10.1016/j.it. 2012.07.003

Romanovsky, A. A., Kulchitsky, V. A., Simons, C. T., Sugimoto, N., and Székely, M. (1997). Febrile responsiveness of vagotomized rats is suppressed even in the absence of malnutrition. Am. J. Physiol. 273 (2), R777-R783. doi:10.1152/ ajpregu.1997.273.2.R777

Romanovsky, A. A., Ivanov, A. I., and Székely, M. (2000). Neural route of pyrogen signaling to the brain. Clin. Infect. Dis. 31 (5), S162-S167. doi:10.1086/317515

Romei, C., Raiteri, M., and Raiteri, L. (2012). GABA transporters mediate glycine release from cerebellum nerve endings: roles of $\mathrm{Ca}(2+)$ channels, mitochondrial $\mathrm{Na}(+) / \mathrm{Ca}(2+)$ exchangers, vesicular GABA/glycine transporters and anion channels. Neurochem. Int. 61 (2), 133-140. doi:10.1016/j.neuint.2012.05.005

Roth, J., and Blatteis, C. M. (2014). Mechanisms of fever production and lysis: lessons from experimental LPS fever. Compr. Physiol. 4 (4), 1563-1604. doi:10. 1002/cphy.c130033

Roth, J., Martin, D., Störr, B., and Zeisberger, E. (1998). Neutralization of pyrogeninduced tumour necrosis factor by its type 1 soluble receptor in Guinea-pigs: effects on fever and interleukin-6 release. J. Physiol. (Lond) 509 (1), 267-275. doi:10.1111/j.1469-7793.1998.267bo.x

Rothwell, N. J., Luheshi, G., and Toulmond, S. (1996). Cytokines and their receptors in the central nervous system: physiology, pharmacology, and pathology. Pharmacol. Ther. 69 (2), 85-95. doi:10.1016/0163-7258(95)02033-0

Rummel, C., Sachot, C., Poole, S., and Luheshi, G. N. (2006). Circulating interleukin-6 induces fever through a STAT3-linked activation of COX-2 in the brain. Am. J. Physiol. Regul. Integr. Comp. Physiol. 291 (5), R1316-R1326. doi:10.1152/ajpregu.00301.2006

Saha, S., Engström, L., Mackerlova, L., Jakobsson, P. J., and Blomqvist, A. (2005). Impaired febrile responses to immune challenge in mice deficient in microsomal prostaglandin E synthase-1. Am. J. Physiol. Regul. Integr. Comp. Physiol. 288 (5), R1100-R1107. doi:10.1152/ajpregu.00872.2004
Sajadi, M. M. (2015). 55-temperature regulation and the pathogenesis of fever. Mandell Douglas Ennett's Principles Practice Infect. Dis. 2015, 708-720. doi:10. 1016/B978-1-4557-4801-3.00055-2

Salvi, V., Vaira, X., Gianello, V., Vermi, W., Bugatti, M., Sozzani, S., et al. (2016). TLR signalling pathways diverge in their ability to induce PGE2. Mediators Inflamm. 2016, 5678046-5678052. doi:10.1155/2016/5678046

Schieferdecker, H. L., Pestel, S., Püschel, G. P., Götze, O., and Jungermann, K. (1999). Increase by anaphylatoxin C5a of glucose output in perfused rat liver via prostanoids derived from nonparenchymal cells: direct action of prostaglandins and indirect action of thromboxane $\mathrm{A}(2)$ on hepatocytes. Hepatology 30 (2), 454-461. doi:10.1002/hep.510300229

Schieferdecker, H. L., Schlaf, G., Jungermann, K., and Götze, O. (2001). Functions of anaphylatoxin $\mathrm{C} 5 \mathrm{a}$ in rat liver: direct and indirect actions on nonparenchymal and parenchymal cells. Int. Immunopharmacol 1 (3), 469-481. doi:10.1016/s1567-5769(00)00038-2

Schiltz, J. C., and Sawchenko, P. E. (2003). Signaling the brain in systemic inflammation: the role of perivascular cells. Front. Biosci. 8, s1321-9. doi:10.2741/1211

Sciences (2003). Glossary of terms for thermal physiology. J. Therm. Biol. 28 (1), 75-106. doi:10.1016/s0306-4565(02)00055-4

Shang, X., Pan, H., Li, M., Miao, X., and Ding, H. (2011). Lonicera japonica Thunb.: ethnopharmacology, phytochemistry and pharmacology of an important traditional Chinese medicine. J. Ethnopharmacol. 138 (1), 1-21. doi:10.1016/ j.jep.2011.08.016

Shu, M., Luo, S. h., Wan, C. m., and Zhang, C. f. (2016). Evidence-based guidelines for the diagnosis and management of acute fever with unknown etiology in Chinese children aged 0-5 years: definitions of relevant terms and partial interpretation of body temperature measurement. Chin. J. Evid. Based Pediatr. 11 (3), 232-234. doi:10.3969/j.issn.1673-5501.2016.03.015

Simons, C. T., Kulchitsky, V. A., Sugimoto, N., Homer, L. D., Székely, M., and Romanovsky, A. A. (1998). Signaling the brain in systemic inflammation: which vagal branch is involved in fever genesis? Am. J. Physiol. 275 (1), R63-R68. doi:10.1152/ajpregu.1998.275.1.R63

Smith, B. K., and Kluger, M. J. (1992). Human IL-1 receptor antagonist partially suppresses LPS fever but not plasma levels of IL-6 in Fischer rats. Am. J. Physiol. 263 (3), R653-R655. doi:10.1152/ajpregu.1992.263.3.R653

Steiner, A. A., Chakravarty, S., Rudaya, A. Y., Herkenham, M., and Romanovsky, A. A. (2006a). Bacterial lipopolysaccharide fever is initiated via Toll-like receptor 4 on hematopoietic cells. Blood 107 (10), 4000-4002. doi:10.1182/blood-2005-114743

Steiner, A. A., Ivanov, A. I., Serrats, J., Hosokawa, H., Phayre, A. N., Robbins, J. R., et al. (2006b). Cellular and molecular bases of the initiation of fever. PLos Biol. 4 (9), e284-e296. doi:10.1371/journal.pbio.0040284

Suebsasana, S., Pongnaratorn, P., Sattayasai, J., Arkaravichien, T., Tiamkao, S., and Aromdee, C. (2009). Analgesic, antipyretic, anti-inflammatory and toxic effects of andrographolide derivatives in experimental animals. Arch. Pharm. Res. 32 (9), 1191-1200. doi:10.1007/s12272-009-1902-x

Sui, F., Lin, N., Guo, J. Y., Zhang, C. B., Du, X. L., Zhao, B. S., et al. (2010). Cinnamaldehyde up-regulates the mRNA expression level of TRPV1 receptor potential ion channel protein and its function in primary rat DRG neurons in vitro. J. Asian Nat. Prod. Res. 12 (1), 76-87. doi:10.1080/ 10286020903451732

Sun, X., Yang, Z., Sun, D., and Zhang, L. (2016). Function of saikosaponin A in reducing body temperature of febrile rats and its relativity with cAMP, PKA. Chin. Pharmacol. Bull. 24 (9), 1212-1215. doi:10.13193/j.issn.1673-7717.2016. 10.065

Székely, M., Balaskó, M., Kulchitsky, V. A., Simons, C. T., Ivanov, A. I., and Romanovsky, A. A. (2000). Multiple neural mechanisms of fever. Auton. Neurosci. 85 (1-3), 78-82. doi:10.1016/S1566-0702(00)00223-X

TangZhishu, Z. Y. L. M., and Bing, W. B. (2012). An study on Gypsum compounds and their antipyretic function and anti-inflammatory mechanisms J. Shaanxi Coll. Traditional Chin. Med. 35 (5), 74-76. doi:10.13424/j.cnki.jsctcm

Thorén, S., and Jakobsson, P. J. (2000). Coordinate up-and down-regulation of glutathione-dependent prostaglandin E synthase and cyclooxygenase- 2 in A549 cells: inhibition by NS-398 and leukotriene C4. Eur. J. Biochem. 267 (21), 6428-6434. doi:10.1046/j.1432-1327.2000.01735.x

Tsai, C. C., Lin, M. T., Wang, J. J., Liao, J. F., and Huang, W. T. (2006). The antipyretic effects of baicalin in lipopolysaccharide-evoked fever in rabbits. Neuropharmacology 51 (4), 709-717. doi:10.1016/j.neuropharm.2006.05.010 
Turrin, N. P., and Rivest, S. (2004). Unraveling the molecular details involved in the intimate link between the immune and neuroendocrine systems. Exp. Biol. Med. 229 (10), 996-1006. doi:10.1177/153537020422901003

Uciechowski, P., and Dempke, W. C. M. (2020). Interleukin-6: a masterplayer in the cytokine network. Oncology 98 (3), 131-137. doi:10.1159/000505099

Vallières, L., and Rivest, S. (1997). Regulation of the genes encoding interleukin-6, its receptor, and gp130 in the rat brain in response to the immune activator lipopolysaccharide and the proinflammatory cytokine interleukin-1beta. J. Neurochem. 69 (4), 1668-1683. doi:10.1046/j.1471-4159.1997.69041668.x

Wan, W., Wetmore, L., Sorensen, C. M., Greenberg, A. H., and Nance, D. M. (1994). Neural and biochemical mediators of endotoxin and stress-induced c-fos expression in the rat brain. Brain Res. Bull. 34 (1), 7-14. doi:10.1016/03619230(94)90179-1

Wang, X., Xu, W., Xu, L., Song, S., Xing, X., and Luo, J. (2018a). Antipyretic effect of Herba ephedrae-ramulus cinnamomi herb pair on yeast-induced pyrexia rats: a metabolomics study. Chin. J. Integr. Med. 24 (9), 676-682. doi:10.1007/ s11655-017-2778-0

Wang, Z., Xia, Q., Liu, X., Liu, W., Huang, W., Mei, X., et al. (2018b). Phytochemistry, pharmacology, quality control and future research of Forsythia suspensa (Thunb.) Vahl: a review. J. Ethnopharmacol. 210 318-339. doi:10.1016/j.jep.2017.08.040

Weber, A., Wasiliew, P., and Kracht, M. (2010). Interleukin-1 (IL-1) pathway. Sci. Signal. 3 (105), 3105. doi:10.1126/scisignal. $3105 \mathrm{~cm} 1$

Whitehouse, M. W., and Butters, D. E. (2014). Paracetamol (acetaminophen): a blessing or a hidden curse? Inflammopharmacology 22 (1), 63-65. doi:10.1007/ s10787-013-0189-1

Wilhelms, D. B., Kirilov, M., Mirrasekhian, E., Eskilsson, A., Kugelberg, U. Ö., Klar, C., et al. (2014). Deletion of prostaglandin E2 synthesizing enzymes in brain endothelial cells attenuates inflammatory fever. J. Neurosci. 34 (35), 11684-11690. doi:10.1523/JNEUROSCI.1838-14.2014

Wisse, B. E., Ogimoto, K., Morton, G. J., Wilkinson, C. W., Frayo, R. S., Cummings, D. E., et al. (2004). Physiological regulation of hypothalamic IL-1beta gene expression by leptin and glucocorticoids: implications for energy homeostasis. Am. J. Physiol. Endocrinol. Metab. 287 (6), E1107-E1113. doi:10.1152/ajpendo. 00038.2004

Wong, W., Lam, C. L., and Fong, D. Y. (2012). Treatment effectiveness of two Chinese herbal medicine formulae in upper respiratory tract infections--a randomized double-blind placebo-controlled trial. Fam. Pract. 29 (6), 643-652. doi:10.1093/fampra/cms027

Woo, K. J., Lim, J. H., Suh, S. I., Kwon, Y. K., Shin, S. W., Kim, S. C., et al. (2006). Differential inhibitory effects of baicalein and baicalin on LPS-induced cyclooxygenase-2 expression through inhibition of C/EBPbeta DNAbinding activity. Immunobiology 211 (5), 359-368. doi:10.1016/j.imbio. 2006.02.002

Wrotek, S., Jędrzejewski, T., Nowakowska, A., and Kozak, W. (2015). Glutathione deficiency attenuates endotoxic fever in rats. Int. J. Hyperthermia 31 (7), 793-799. doi:10.3109/02656736.2015.1067333

Xian, J., Guan, L., and Zhao, H. (2010). Clinical observation of 54 cases of high fever with acute upper respiratory tract infection treated by Qingkailing Guide China Med. 16 (5), 35-37. doi:10.15912/j.cnki.gocm

Xie, X., Jiang, S., Zou, X., Zhou, Q., Wen, E., and Xue, J. (2009). Study on antipyretic effect and mechanism of Jinyinhua in pyretic rabbits. lishizhen Med. materia Med. Res. 20 (3), 691-692.

Xu, Y., Oliverson, B. G., and Simmons, D. L. (2007). Trifunctional inhibition of COX-2 by extracts of Lonicera japonica: direct inhibition, transcriptional and post-transcriptional down regulation. J. Ethnopharmacol. 111 (3), 667-670. doi:10.1016/j.jep.2007.01.017

Yan, L., and Fan, S. Q. (2019). Application effect of Qingkailing injection in the treatment of febrile convulsion in children. Zhong Yi Zhong Yao 4 (12), 102-104. doi:10.19347/j.cnki.2096-1413.201728057

Yan, S. K., Xin, W. F., Luo, G. A., Wang, Y. M., and Cheng, Y. Y. (2005). Simultaneous determination of major bioactive components in Qingkailing injection by highperformance liquid chromatography with evaporative light scattering detection. Chem. Pharm. Bull. 53 (11), 1392-1395. doi:10.1248/cpb.53.1392

Yan, X. D., Chen, L. Z., and Zhang, H. M. (2007). Shuanghuanglian injection liquid on the treatment of 120 cases of respiratory tract infection. Guiding J. TCM 13 (7), 65-67. doi:10.13862/j.cnki.cn43-1446/r.2007.07.033
Yang, C. S., Lin, N. N., Tsai, P. J., Liu, L., and Kuo, J. S. (1996). In vivo evidence of hydroxyl radical formation induced by elevation of extracellular glutamate after cerebral ischemia in the cortex of anesthetized rats. Free Radic. Biol. Med. 20 (2), 245-250. doi:10.1016/0891-5849(95)02042-x

Yang, F., Dong, X., Yin, X., Wang, W., You, L., and Ni, J. (2017). A review of traditional uses, botany, phytochemistry, pharmacology, and toxicology. Biomed. Res. Int. 2017, 7597596-7597612. doi:10.1155/2017/7597596

Yang, J., Shen, S., Song, J., Li, Z., and Zhang, Q. (2008). Effects of volatile oil from ligusticum chuanxiong on cAMP content in the hypothalamus of rats with yeast fever model. JETCM 17 (7), 961-962. doi:10.3969/j.issn.1004-745X.2008.07.047

Yang, J., Song, J., Hu, R., Hua, H., and Li, L. (2009). Effect of essential oil of ligusticum chuanxiong hort on the expressions of COX-2 in hypothalamus of fever rat. Lishizhen Med. materia Med. Res. 20 (2), 315-316.

Yang, X., and Meng, Q. G. (2009). Reducing fever chemistry composition study of scutellaria. Chinese Archives Tradit. Chinese Med. 27 (6). doi:10.13193/j. archtcm.2009.06.64.yangx.044

Yang, Y. (2018). Observation on treating bacterial respiratory infection with the Shuanghuanglian oral liquid. Clin. J. Chin. Med. (8), 16-19. doi:10.3969/j.issn. 1674-7860

Yasuda, T., Endo, M., Kon-no, T., Kato, T., Mitsuzuka, M., and Ohsawa, K. (2005). Antipyretic, analgesic and muscle relaxant activities of pueraria isoflavonoids and their metabolites from Pueraria lobata Ohwi-a traditional Chinese drug. Biol. Pharm. Bull. 28 (7), 1224-1228. doi:10.1248/bpb.28.1224

Ye, J. B. (2019). Study on the effect of shuanghuanglian oral liquid on acute tonsillitis in children. Electron. J. Clin. Med. Lit. 6 (84), 177-178. doi:10.16281/j. cnki.jocml.2019.84.132

Ye, L., Tao, Y., Wang, Y., Feng, T., and Li, H. (2015). The effects of baicalin on the TLR2/4 signaling pathway in the peripheral blood mononuclear cells of a lipopolysaccharide-induced rat fever model. Int. Immunopharmacol. 25 (1), 106-111. doi:10.1016/j.intimp.2014.12.028

Yu, C. Q., Chen, J. P., Zhong, Y. M., Zhong, X. L., Tang, C. P., Yang, Y., et al. (2018). Metabolomic profiling of rat urine after oral administration of the prescription antipyretic Hao Jia Xu Re Qing Granules by UPLC/Q-TOF-MS. Biomed. Chromatogr. 32 (11), e4332. doi:10.1002/bmc.4332

Zampronio, A. R., Soares, D. M., and Souza, G. E. (2015). Central mediators involved in the febrile response: effects of antipyretic drugs. Temperature 2 (4), 506-521. doi:10.1080/23328940.2015.1102802

Zeisberger, E. (1999). From humoral fever to neuroimmunological control of fever. J. Therm. biol. 24 (5-6), 287-326. doi:10.1016/s0306-4565(99)00033-9

Zelová, H., and Hošek, J. (2013). TNF- $\alpha$ signalling and inflammation: interactions between old acquaintances. Inflamm. Res. 62 (7), 641-651. doi:10.1007/s00011013-0633-0

Zeng, X. Y., Yuan, W., Zhou, L., Wang, S. X., Xie, Y., and Fu, Y. J. (2017). Forsythoside $\mathrm{A}$ exerts an anti-endotoxin effect by blocking the LPS/TLR4 signaling pathway and inhibiting Tregs in vitro. Int. J. Mol. Med. 40 (1), 243-250. doi:10.3892/ijmm.2017.2990

Zhang, C. Y. (2019). Clinical study of Qingkailing injection in the treatment of acute upper respiratory tract infection. World Latest Medicne Inf. 19 (45), 160-162. doi:10.19613/j.cnki.1671-3141.2019.45.105

Zhang, G., Zhao, J., He, L., Yan, S., Zhuo, Z., Zheng, H., et al. (2013a). Reduning injection for fever, rash, and ulcers in children with mild hand, foot, and mouth disease: a randomized controlled clinical study. J. Tradit Chin. Med. 33, 733. doi:10.1016/s0254-6272(14)60005-4

Zhang, H., Chen, Q., Zhou, W., Gao, S., Lin, H., Ye, S., et al. (2013b). Chinese medicine injection shuanghuanglian for treatment of acute upper respiratory tract infection: a systematic review of randomized controlled trials, Evid. Based Complement. Alternat Med. 2013, 987326-987335. doi:10.1155/2013/987326

Zhang, M. Y., Li, Y. K., Yan, W. J., Lin, C. R., Jin, L., Zhnag, J. Y., et al. (2010). Antiinflammatory and antipyretic effect of new Houttuynia Cordata injection and the mechanism Chinese J. New Drugs 19 (9), 775-779. doi:10.1016/j.jep.2005.09.012

Zhang, X., Wang, Y., Li, S., Dai, Y., Li, X., Wang, Q., et al. (2019). The potential antipyretic mechanism of Gardeniae Fructus and its heat-processed products with plasma metabolomics using rats with yeast-induced fever. Front. Pharmacol. 10 491. doi:10.3389/fphar.2019.00491

Zhang, Z., La Placa, D., Nguyen, T., Kujawski, M., Le, K., Li, L., et al. (2019). CEACAM1 regulates the IL-6 mediated fever response to LPS through the RP105 receptor in murine monocytes. BMC Immunol. 20 (1), 7. doi:10.1186/s12865-019-0287-y 
Zhang, Z., Qin, L., Peng, L., Zhang, Q., Wang, Q., Lu, Z., et al. (2016). Pharmacokineticpharmacodynamic modeling to study the antipyretic effect of Qingkailing injection on pyrexia model rats. Molecules 21 (3), 317. doi:10.3390/molecules21030317

Zhang, Z., Lu, F., Liu, H., Zhao, H., Liu, Y., Fu, S., et al. (2017). An integrated strategy by using target tissue metabolomics biomarkers as pharmacodynamic surrogate indices to screen antipyretic components of Qingkaikling injection. Sci. Rep. 7 (1), 6310. doi:10.1038/s41598-017-05812-0

Zhu, J., Luo, C., Wang, P., He, Q., Zhou, J., and Peng, H. (2013). Saikosaponin A mediates the inflammatory response by inhibiting the MAPK and NF- $\mathrm{KB}$ pathways in LPS-stimulated RAW 264.7 cells. Exp. Ther. Med. 5 (5), 1345-1350. doi:10.3892/etm.2013.988
Conflict of Interest: The authors declare that the research was conducted in the absence of any commercial or financial relationships that could be construed as a potential conflict of interest.

Copyright $\odot 2021 \mathrm{Ma}$, Liu, Luo, He, Wang, Huang, Han, Yang, Xu and Zhang. This is an open-access article distributed under the terms of the Creative Commons Attribution License (CC BY). The use, distribution or reproduction in other forums is permitted, provided the original author(s) and the copyright owner(s) are credited and that the original publication in this journal is cited, in accordance with accepted academic practice. No use, distribution or reproduction is permitted which does not comply with these terms. 


\section{GLOSSARY}

TCM traditional chinese medicine

NSAIDs nonsteroidal anti-inflammatory drugs

Poly-IC polyinosinic polycytidylic acid

ACE-2 angiotensin-converting enzyme-2

LPS lipopolysaccharides

PAMPs pathogen-associated molecular patterns

TLRs toll-like receptors

IL-1 interleukin-1

IL-6 interleukin-6

TNF- $\alpha$ tumor necrosis factor $\alpha$

IL-1RA IL-1 receptor antagonist

PGE2 prostaglandin E2

Cox-2 cyclooxygenase 2

IKK2 IкB kinase 2

rh TNF human recombinant TNF

mPGES-1 PGE synthase-1

I.V intravenous

I.C.V intra cerebro-ventricular

BBB blood-brain barrier

Kc kupffer cells

C5a complement component $5 \mathrm{a}$
PLA2 phospholipase A2;

IL-6R IL-6 receptor

NMDA N-methyl-D-aspartate

ROS reactive oxygen species

iNOS inducible nitric oxide synthetase

5-HT 5-hydroxy tryptamine

GABA $\gamma$-aminobutyric acid

OVLT organum vasculosum of lamina terminalis

POA preoptic-anterior hypothalamic area

AA arachidonic acid

CVOs circumventricular organs

NTS nucleus of the solitary tract

NE norepinephrine

PKA protein kinase A

IкB $\boldsymbol{\alpha}$ NF- $\kappa B$ inhibitor $\alpha$

RCMEC rat cerebral microvascular endothelial cells

bEnd. 3 brain microvascular endothelial cells

FTA forsythoside a

DRG dorsal respiratory group

POAH preoptic anterior hypothalamus

CGA Chlorogenic acid

AURI acute upper respiratory tract infection 